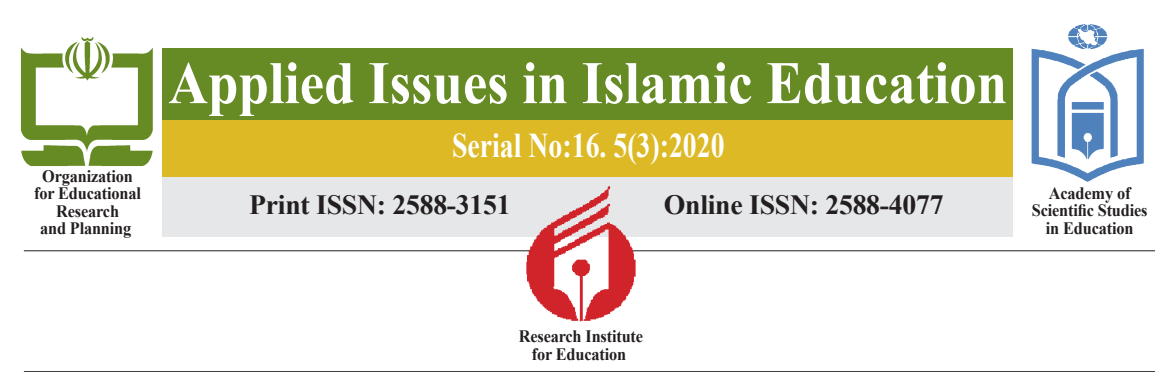

\title{
The Basics, Goals and Principles of Students' Religious Education Based on the Acceptance of the Hermeneutic Circulation between Thoughts, States and Sctions in Transcendental Philosophy
}

\begin{abstract}
"Mohammad Reza Haji Rafi ${ }^{1}$ m Abulfazl Ghafari ${ }^{2}=$ Jahangir Masoudi $^{3}=$ Mohsen Imani $^{4}$
- Objective: The main purpose of this paper is to achieve a new and more comprehensive reading of transcendental philosophy in terms of the relationship between the components of thoughts, states, and actions, as well as how it affects the consequences of the religious education model. In the common view, man's thoughts affect his states, and his states affect his actions. It seems that in the above perception, which is the dominant opinion, the relationship between the thoughts, states and actions is one-sided and linear, and subsequently, it tends to highlight the theoretical classes and emphasis on educational content which has not yielded valuable results yet. This paper investigates the Mulla Sadra's view on the main question 'What educational implications does Mulla Sadra's anthropological view of the relationship between thoughts, states, and actions provide in terms of the basics, goals, and principles of religious education?'
\end{abstract}

- Method Since the philosophical studies are mainly of theoretical nature, this study seeks to refer to Mulla Sadra's works including Asfar Arba'a, al-Mabda' walMa'ad, Rasa'il Falsafi, Shawahid al-Robubiyya, Kasr Asnam Jahiliyya, Tafsir Quran Karim, and the exposition written for his works, such as Rahiq Makhtum, Jawadi Amoli), and the Persian exposition of Asfar (Hassan-zada Amoli) to find the goal and the principles of religious education through the philosophical analogy and Frankena's inferential method.

Finding The results of this research revealed that Mulla Sadra believed in the interaction of each of the three aforementioned components and in other words, believed in the Hermeneutics Circulation between the three components of thoughts, states and actions. Thus, in transcendental philosophy, not only the linear view has not been weighted, but the multifaceted effects of the components and the promotion of human existence in this increasing course are emphasized.

- Conclusion According to such attitude, the basics, goals and principles of religious education considered by Mulla Sadra, instead of cognitive and one-sided education, emphasizes the multifaceted education.

Keywords: religious education, Mulla Sadra, thoughts, states, actions, students.

Citation: Mohammad Reza Haji Rafi‘., \& Abulfazl Ghafari., \& Jahangir Masoudi., \& Mohsen Imani. (2021). The Basics, Goals and Principles of Students' Religious Education Based on the Acceptance of the Hermeneutic Circulation between Thoughts, States and Sctions in Transcendental Philosophy. Applied Issues in Islamic Education, 5(4): 57-88.

Received: $2021 / 01 / 25$ Accepted: 2021/02/20

1. A Ph.D. Student in the Philosophy of Education, the Department of Educational Sciences, Faculty of Educational Sciences, Ferdowsi University of Mashhad, Mashhad, Iran.

E-mail: hajrafie@gmail.com. (iD) 0000- 0001-9779-1598

2. Corresponding Author: An Assistant Professor in the Philosophy of Education, Department of Educational Sciences, Faculty of Educational Sciences, Ferdowsi University of Mashhad, , Mashhad, Iran. E-mail: ghaffari@um.ac.ir. (iD 0000- 0009-9245-5701

3. A Professor in the Islamic Philosophy and wisdom, the Deartment of Islamic Philosophy University and wisdom, the Faculty of Theology, Ferdousi of Mashhad, Mashhad, Iran

E-mail: masoudi-g@um.ac.ir. (D) 0000- 0002-6753-0693

4. An Associate Professor in the Philosophy of Education, the Department of Humanities, the Faculty of Humanities, Tarbiat Modares University, Tehran, Iran.

E-mail: Email: emanim@modares.ae.ir. (iD 0000-0002-4124-6133 


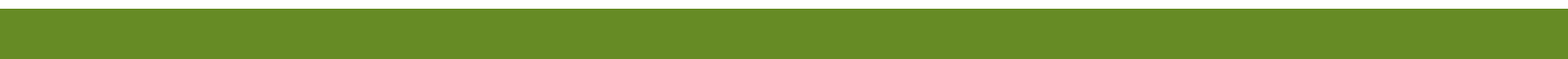



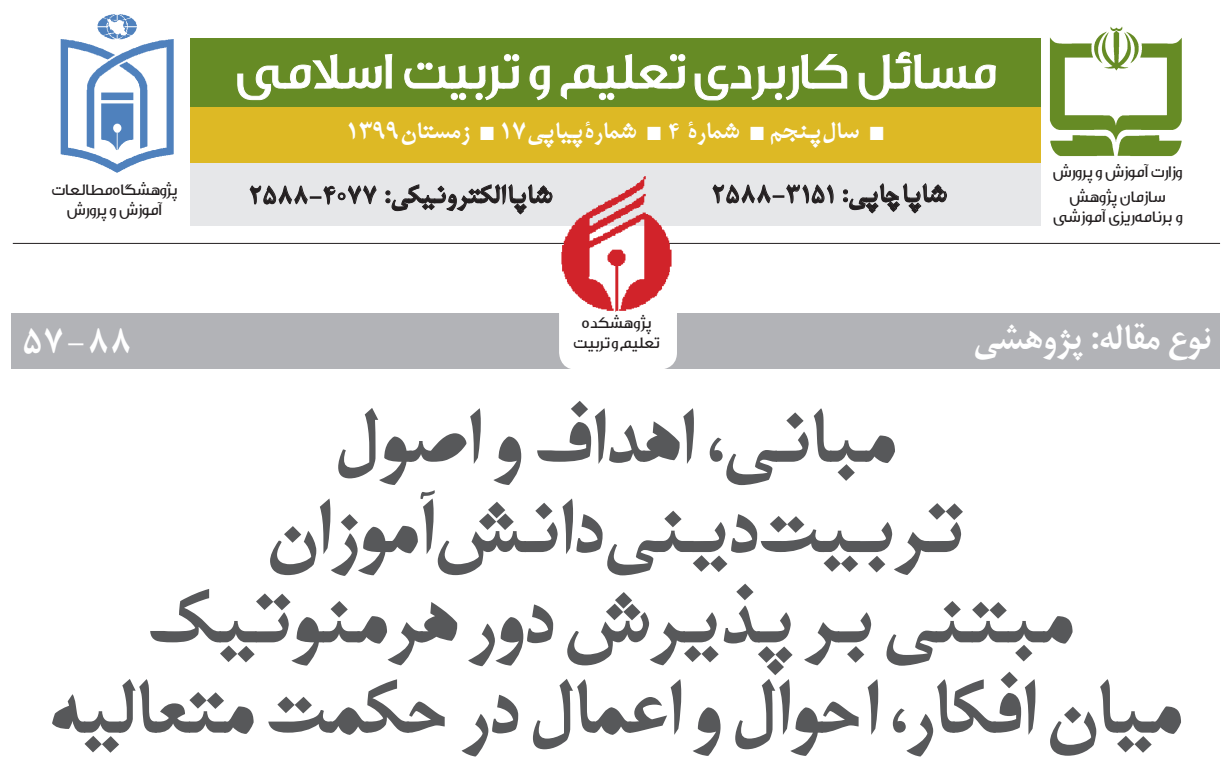

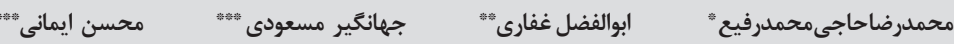

$0{ }_{0 \rightarrow 0}$

ه هدف: رسيدن به قرائت جديد و كامل ترى از حكمت متعاليه در خصوص ارتباط ميان مؤلفههاى

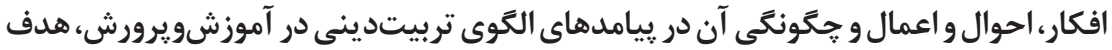

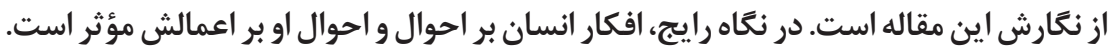

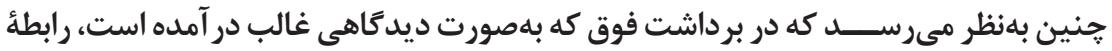

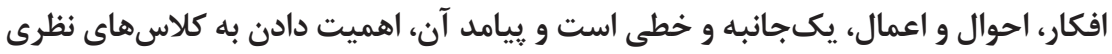

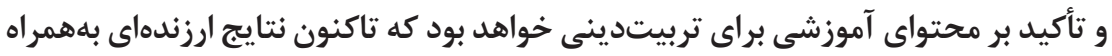

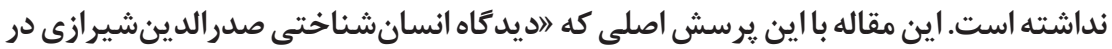

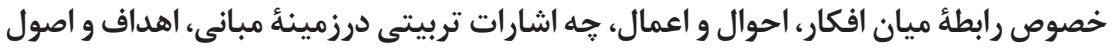

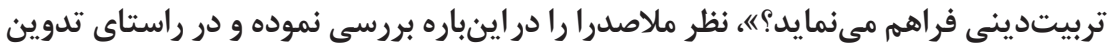
الكوى تربيتدينى بر اين اساس، بر آمده است فئ. • روش: روش يثروهش استنتاجى است.

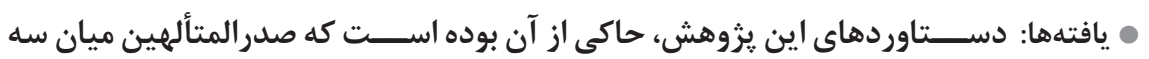

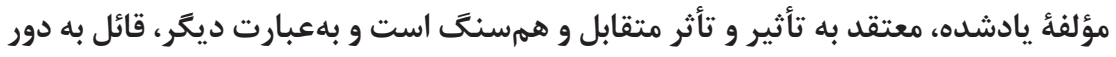
४

* دانشجوى دكترى فلسفه تعليم و تربيت، دانشكده علوم تربيتى و روانشناسى، دانشكاه فردوسى مشهد، مشهد. ايران. Email: hajrafie@gmail.com iD 0000-0001-9779-1598 Email: ghaffari@um.ac.ir (iD) 0000-0009-9245-5701 
هرمنوتيك ميان سه مؤلفه افكار، احوال و اعمال است؛ بنابر اين، در حكمت متعاليه، نهتنها

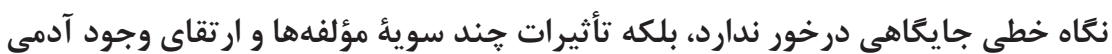
در اين سير رو به تزايد، مورد تأكيد است.

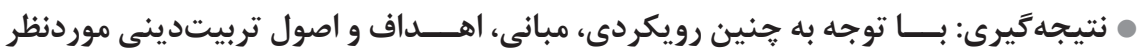

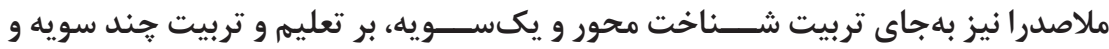
جندجانبه نغر تأكيد دارد.

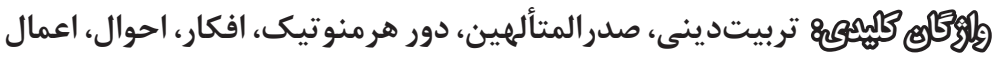

\section{مقدمه}

تحقيقات حاكى از آن اســت كه خروجى آموزش خويرورش در كشـــورهاى مسلمان و غيرمسلمان در سالهاى اخير، علىرغم توفيقات زياد در بهرهمندى از دانش نوين، تربيت مطلوبى را از حيث اخلاق و دين بهدســت نياورده اســت (داوودى، موس ا ، يزدخواستى،

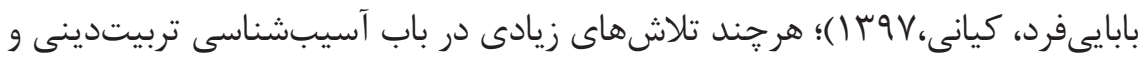
راهكارهاى متفاوت انجامگرفته تا كارامدى آن را افزايش دهند.

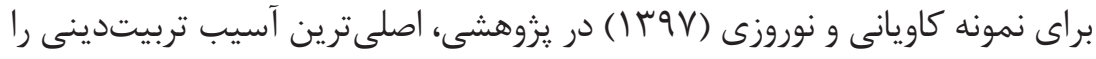

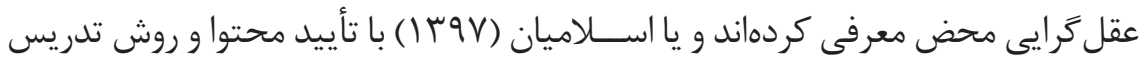
موجود، مشكل را در ساختار نظام رسمى تعليموتربيت مى داند. همجنين داودى ( يس از بررســى امكان تربيتدينى، با افرادى جون هرســت كه امكان تربيتدينى را رد

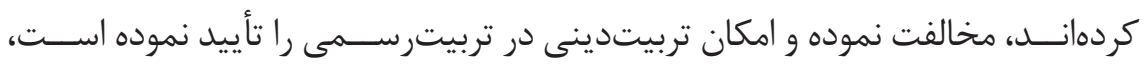
لكن تمام يزوهشها، تربيتدينى را در كنار ســاير ســاحتهاى تربيت قرار مىدهند و

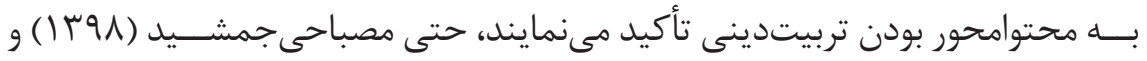

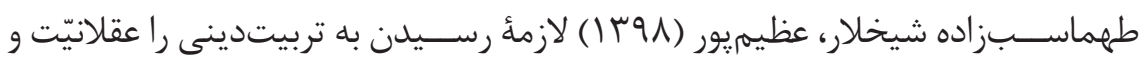
شرط تحقق آن را تعقّل و شناخت معرفى مى كند. به نظر مىرسد كه تربيتدينى را مىتوان به دو صورت مورد مداقه قرارداد. در رويكرد

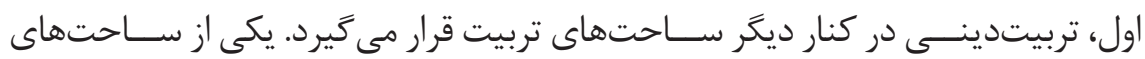
انســان، ساحت باورها و عقايد دينى است؛ آنَّونه كه تربيت سياسى، اجتماعى، اخلاقى 
و ساير انواع تربيت وجود دارد، در كنار آنها تربيتدينى نيز وجود دارد؛ بر همين اساس، تربيتدينى با تربيت اخلاقى در يك ساحت قرارگرفته و از ساير ساحتها جدا گشتنه است.

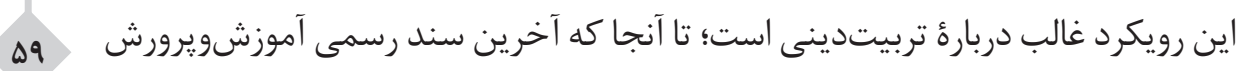
نيز، به تفكيك ســاحتها و ابعاد تربيت يرداخته است؛ درحالى كه مصباحيزدى (1 (1) معتقد اســت: اين گونه نگًاه، نهتنها خدمت به ديــن نخواهد بود، بلكه تخريب دين و در راستاى خدمت به سكولاريسم مىباشد. براى نمونه اخر تربيت سياسى و دينى را جدا در نظر گيرند، به جدايى دين از سياست و سكولار كردن آن دامن زدهاند. رويكـــرد دوم كه كمتر موردتوجه قراركرفته اين اســت كه تربيتدينى، جهت كيرى خاصى است كه دين به تمام امور انسانى مىبخشد و به قول افلاطون: هر تربيتى كه دينى نباشل، ناقص است و باطل و هر دولتى كه شهروندانش /ز /ين

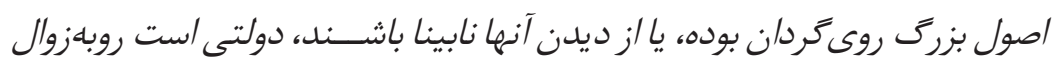

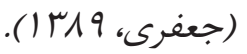

در ايــن نــاه، تربيتدينى، همعرض ســاير تربيتها (مانند تربيتشـــاختى يا عاطفى) لحاظ نمى شـــود؛ بلكه دين تمام شئونات آدمى را در برمى خيرد و انسان را در راستاى رضاى الهى سير مىدهد؛ لذا اخر قرار است تربيتدينى را در تمام ساحتهاى

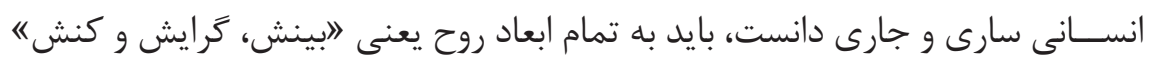
(مصباحيزدى، M M I ) توجه شــود و اينكه در رويكردهاى متفاوت، فقط به جنبهاى از بعدِ روح، توجه مىشــود، بهدليل آن است كه تربيتدينى رادر عرض تربيتهاى ديكر قرار مى دهند.

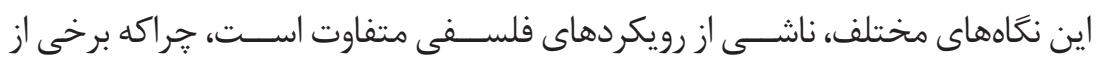
فيلسوفان از تأثير يكجانبة علم بر احوال و اعمال و برخى از تأثير يكجانبهُ اعمال بر افكار سخن مى گويند. براى نمونه، افلاطون در بحث اخلاق، برآن است كه عمل نيك در به نيكى است. درصورتى كه انسان ها به كار نيك، علم داشته باشند، بدى نمى كنند (فروغى،

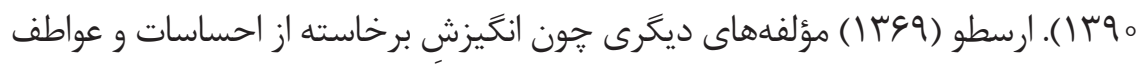

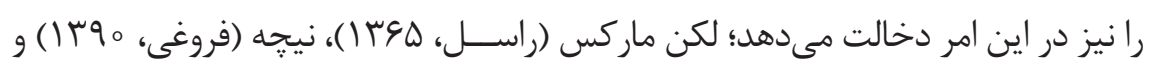

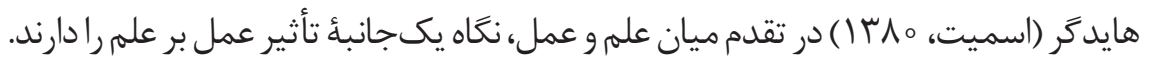

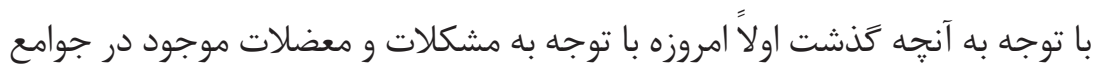


مختلف، گرايش به يثروهشهــاى مبنايى در خصوص باورها و ترويج دين و ديندارى، از اهميت و ضرورت بالايى برخوردار گرديده است (خالق خواه و مسعودى، 9 \سا ، مرزوقى و

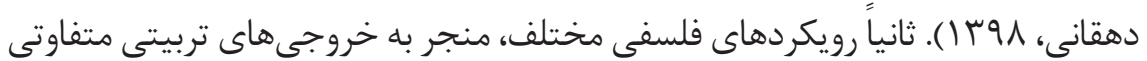
مىشود كه نگاه رايج و يكجانبهَ كرايانه در برخى از رويكردهاى فلسفى منجر به جدايى تربيتدينى از ساير تربيتها گشته و نيز به يكى از ساحتهاى انسانى از جمله شناخت، توجهى بيشترى شده و كمتر به عواطف و اعمال دينى توجه مىشود؛ لكن به نظر مىرسد كه ابتدا بايد نگًاه را نســبت به تربيتدينى تغيير داده و سِيس در فرآيند تربيتدينى از يك جانبهَ

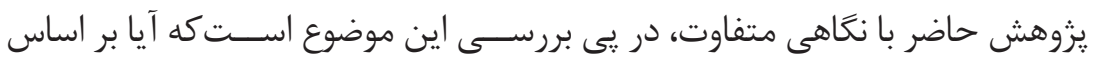
ديدگاه صدر الدينشيرازى، ميان افكار، احوال و اعمال انسان رابطهاى متقابل وجود دارد؟ و اين نَاه، منتج به جهه مبانى، اهداف و اصولى درزمينهُ تربيتدينى دانش آموزان خواهد

\section{مبانى نظرى و يِيشينه هيخوهش}

جهت ورود به بحث مبانى نظرى ضرورى اسـت تا به تعريف مفاهيم اصلى يزوهش تهر

$$
\text { يرداخته شود. }
$$

قــواى وجودى انســـان از نظر كلى ســـهـ قوه اســـ؛ عالمه، شـــوقيه و عامله كه در تمامى كارهـــاى ارادى انســان ها دخالت دارند.كار قــوهُ عالمه، دركى كـــــن، تجزيه، تحليــل و تركيب صور ذهنى اســت (مطهرى، اوس|). آنجـــهـ در اين يزوهش بهعنوان افكار موردنظر اســـ، شـــاختهاى انسان اسـت كه برآمده از قوه عالمهاند. همجنـين منظـــور از احوال در اين يزوهش، آن حالات و احساســاتى هســـتـند كـــهـ برآمده از قوه شـــوقيهاند. در اين يثروهــش، عواطف نيز زيرمجموعـــهُ احوال، قـــرار مى گيرند. اعمال نيز امر برآمده از قوه عامله بشر هستند كه ارادى بودن و نقشآفرين بودن شخص در آن بايد وجود داشته باشد (Dancy\& Sandis, 2015)؛ بنابراين شناختها، نتيجه قوه عالمه و احوال، محصول قوه شوقيه و اعمال، برآمده از قوه عامله انسان هستند؛ اما در بسيارى از مواضع، سه مورد دوم بهجاى سه مورد اول هم به كار زرفته مىشوند. تعريف غالب از دور هرمنوتيك نيز آن است كه در فهمم متن، شناخت اجزاء بر شناخت 
كل و شــناخت كل بر شناخت اجزاء، تأثير گذار است؛ اين تعريف، تعريفى محدودكنـنه بـــراى دور هرمنوتيك اســـ؛ جراكه دور هرمنوتيكى محدود به متــن نبوده و اعمال و

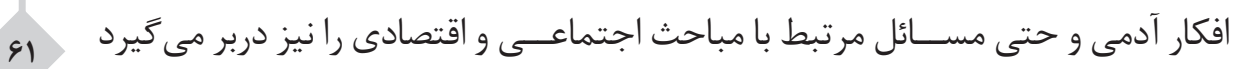

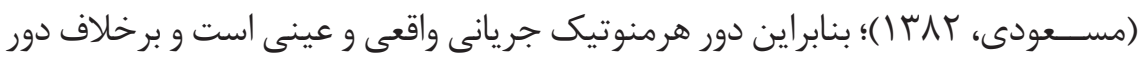

منطقى كه باطل است، امر محال نيست. استفاده از اصطلاح دور هرمنوتيكى در اين يزوهش، به جهرت تأثير و تأثرى است كه مؤلفه ها بهصورت همروزن، بر يكديگر دارند. البته استفاده از دور هرمنوتيك با اين نغاه عام، مسبوق به سابقه است. براى نمونه؛ در تحقيقى، ادعامىشود كه ميان ورزش و هنر، ارتباط وجـــود دارد كه آن را از طريــق دور هرمنوتيك اثبات مىنمايد كه دور هرمنوتيك ميان

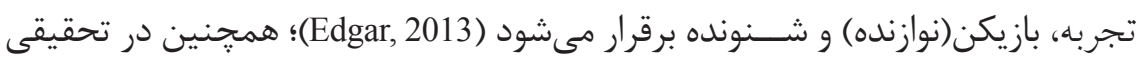
ديخر، يكى از كاربردهاى عملى از دور هرمنوتيك براى نوشتن بيشينهُ يثوهش در مقالات

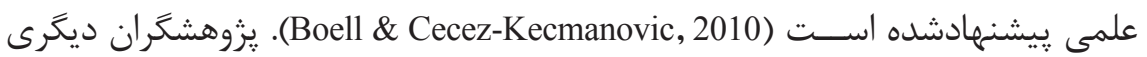
(Lawler\& Trevatt\& Elliot\& Leary, 2019)، در خصوص بيمارى ديابت و يرستاران آنها، از دور هرمنوتيك در مطالعه و جمعآورى شواهد موردنياز خود استفاده كردهاند. جنانجه

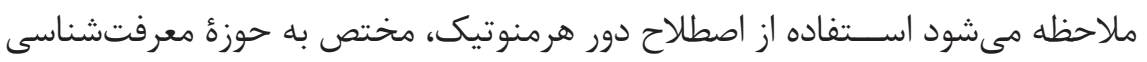
نيست و مى تواند در حوزه وجودشناسى و انسانشناسى نيز كاربرد داشته باشد.

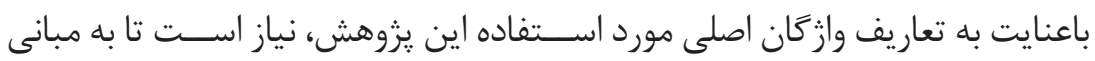

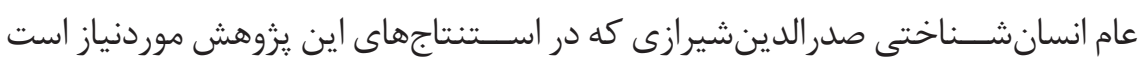
يرداخت. اتحاد عاقل و معقول: يعانه شدن ادراك كننده و ادراكشونده، از نوع وجودى است

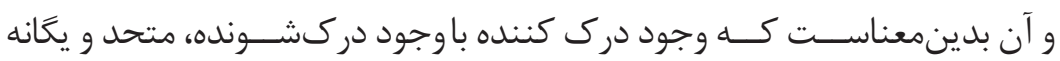

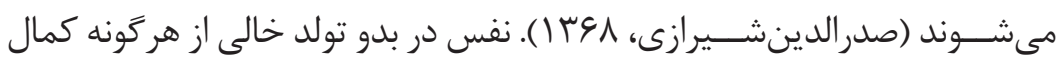
است و با ادراكاتش و نيز اتصال وجودى به مدرك خود، ارتقاء مىيابد. مســاواق وجود بـ عله: در نغاه صدرالدينشيرازى (I I الف) نفس، امرى مادى اســت كه با اولين ادراك، فعليت يافته و عالم مى كردد و نســـبت هريك از مراتب نفس كه عين خود اوسـت با هر صورت ادراكى بهمنزله يك ماده و صورت است. طبق نظر صدر الدينشــيرازى علم از سنخ وجود است و آدمى با رشد علم خود بر 
مرتبـُ وجودى خود مىافزايد و با توجه به اين مبنا، در نوع انسان نيز مرتبـُ متفاوتى

$$
\text { نسبت به افرادِ نوع كسب مىنمايد. }
$$

رابطةُ نظر و عمل: جون صدرالدينشــيرازى، قائل بر 》اصالت وجوده است و آن را

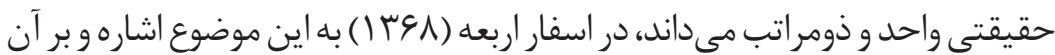
تأكيد مىنمايد كه صفاتى نظير علم، قدرت، حيات، اراده و حتى عمل اوصافى هستند كه از وجود نشأت گرفته و سرمنشأ واحدى دارند و درواقع امورى مترادف يكديخرند وى صراحتاً تأكيد دارد كه بين قوه عامله و عالمه و برعكس، تفكيكى وجود ندارد.

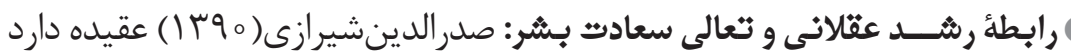
كه ســـادت از ســـنخ وجود و لذا مقول به تشكيك است، يس سعادت را نيز امرى تشكيكى دانسته كه افضل، اكمل و اشرف آن را مختص به حضرت بارى تعالى مى داند و ضعيفترين و يستترين آن را در وجود هيولا، زمان و حركت و نظاير آنها معرفى مى كند. از نظر صدرالدينشــيرازى (هو (1) اسعادت در موجوداتِ عقلانى، برتر، لذتبخشتر و كاملتر است نسبت به سعادت در موجودات مادى و دنيوى" است؛ يس سعادت امرى وجودى است، با ارتقاى رشد عقلانى، وجود رشد نموده و با رتقاى وجود، تمامى صفات وجودى آدمى از جمله تعالى ســادت بشرى رخ خواهد داد. رابطةُ احساسات در معادلات وجودى انســان: صدرالدينشيرازى (I IVDQ ) معتقد است: انسان با هر جيزى كه نسبت به آن محبت (عاطفه) نشان دهد، نوعى از اتحاد وجودى با آن ييدا خواهد نمود؛ در نتيجه ضمن اينكه مطلوب اســت با موضوعات ارزشمند و متعالى، ارتباط برقرار نمايد، نوع نخرش خود را به مبداء و واجبالوجود

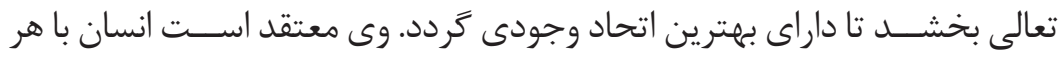

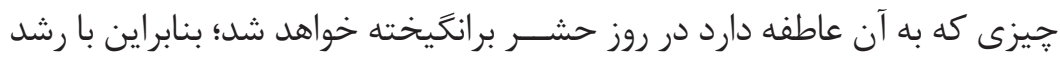
عواطف كه از صفات وجودى انســان است، وجود انسان ارتقاء مى يابد و با توجه به مبناى مساوقت وجود با علم، در اثر ارتقاى وجودى كه از رشد عواطف كسب نموده

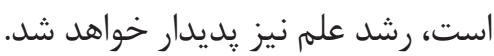

حكماى اســلامى در نســبت ميان افكار، احوال و اعمال، عقيده دارند كه قوه عامله تحت تأثير قوهُ شــوقيه و قوه شوقيه مؤثر از قوه عالمئ مدركه است (مطهرى، اعس |). از نظر ابنسينا (r r I ) براى برانتخيخته شدن اراده يا همان شوق بايد تصوّر مفيد بودن و يا 


\section{$\Delta V-\wedge \Lambda$}

مضر بودن امرى وجود داشته باشد. تصوّر مفيد بودن يا مضر بودن، يا از تخيّل و يا از تعقّل

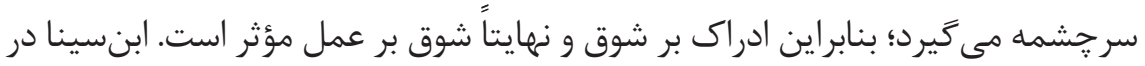
كتاب عيون الحكمه خويش به بررســى نسبت ميان افكار، احوال و افعال يرداخته است و

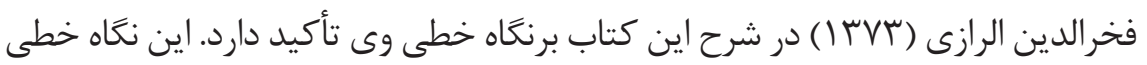
رايج، در نمودار ا، ترسيم شده است.

\section{اعمال}

احوال

افكار

\section{نمودار ا. نحَاه خطى ميان افكار، احوال و اعمال}

در نگاه اول، صدرالدينشيرازى (IV I الف) نيز قدم نخست را تصوّر يك امر مىداند و سيس تصديق به مفيد بودن و بعد از آن شوق جذب امر موافق با طبع آدمى، قوه عامله

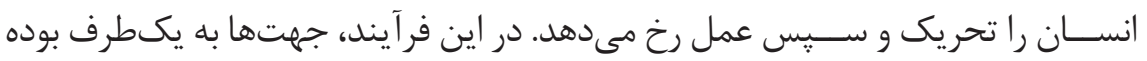

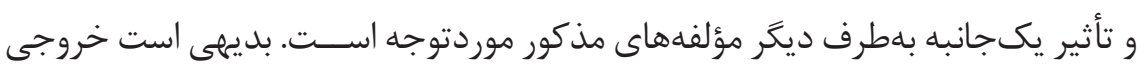
تربيتى اين نحاه، تعليهم و تربيت يكجانبه و شــناخت گراو تمركز بر كلاسهاى تئورى و نظرى در جهت معرفتافزايى بوده و برنامهريزى آموزش رسمى نيز بر اين اساس طراحى گرديده است. هر جند اين رويكرد، صحيح و قابل استناد است، اما كامل به نظر نمىرسد. در اين يزوهش علاوه بر استفاده از تأثير افكار بر احوال، و احوال بر اعمال، تأثير متقابل و دورى مؤلفهها نيز موردتوجه قرار مى گيرد.

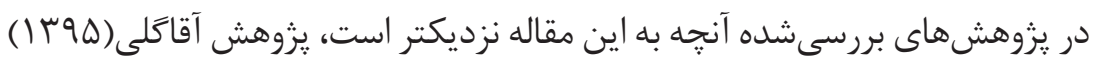
اســت كه ايمان را حاصــل همرَرايى عقل و عاطفه از نظر صدرالدينشــيرازى مى داند. ايشــان، دو مؤلفهُ اصلى از مؤلفههاى موردبحث در اين يثوهش را مورد بررسى قرار داده

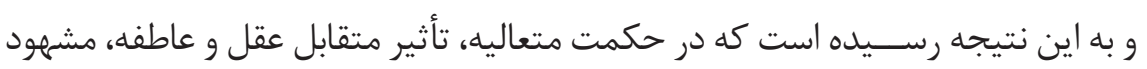

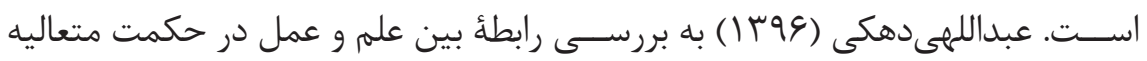
يرداخته اســت. وى در اين تحقيق نتيجه مى گيرد كــهـ علم و عمل در حكمت متعاليه

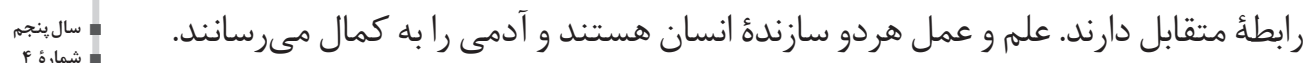

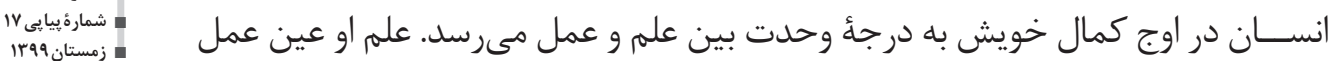




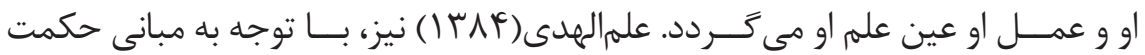
متعاليه و آيات قرآن كريهم به دلالتهاى آن در برنامه درسى اشارهكرده و به نتايجى جون

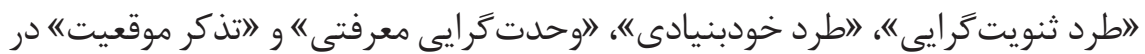
بنيادهاى تربيت اسلامى دستيافته است. از نكاه ايشان نيز صدرالدينشيرازى، فيلسوفى

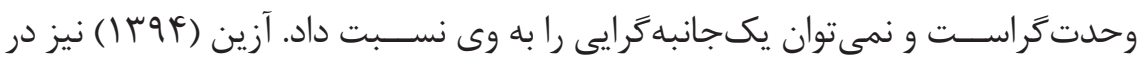
بســتر حكمت متعاليه بر وحدت گرايى به ابعاد وجودى و زندگى دانش آموز تأكيد دارد. بر اســاس اين رويكرد، تفكيك ساحتهاى وجودى انسان براى طراحى برنامه درسى را

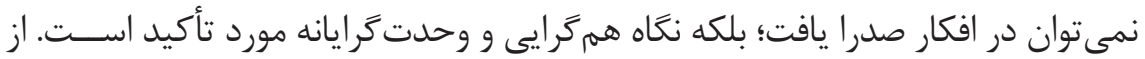
نخاه آزين، صدرالدينشيرازى فيلســوفى وحدت

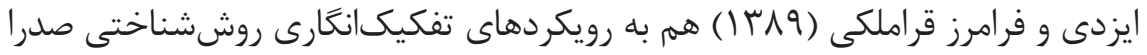

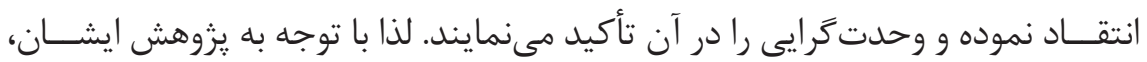

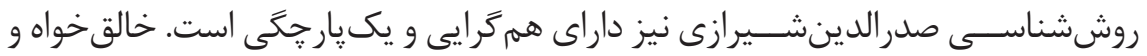

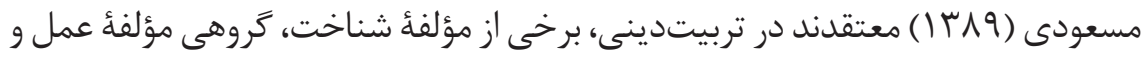

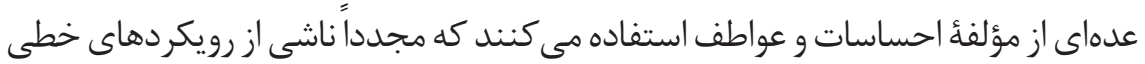
و اهميت دادن به يك قوه از قواى انسانى در تربيت است. باتوجه به مطالبى كه حذشت،

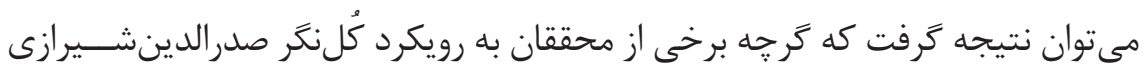
اذعان دارند، لكن هنوز نحَاه يكجانبه گرايانه در خروجى مدلهاى تربيتى، رواج دارد.

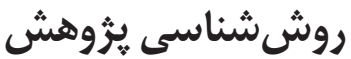

از آنجائى كه يثروهشهاى فلســفى، عمدتاً ماهيتى نظر ورزانه دارند، اين يزوهش نيز

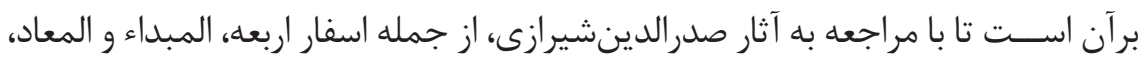

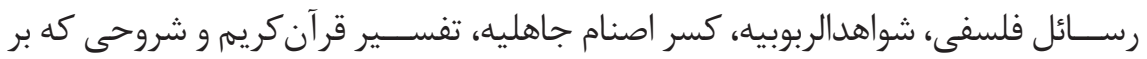

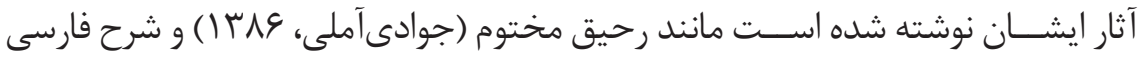
اسفار (حسنزادهآملى، IN IVV)، به يرسش تحقيق در بخش مبانى فلسفى با روش قياسى و براى يافتن اهداف و اصول تربيتدينى، از الكوى اصلاحشده فرانكنا (باقرى، ویى ا ) با ابزار فيشبردارى ياسخ دهد. از آنجائى كه صدرالدينشيرازى فيلسوف تعليم و تربيت نيست،

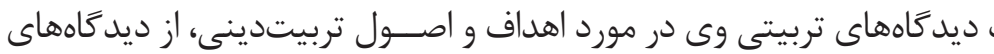


فلسفى وى در خصوص هستى، معرفت، انسان و ارزش، استنتاج شود. استنتاج قياسى در روش اصلاحشده فرانكنا، روشى است كه به كمك "بايدآغازين" كه بالاتر از آن براى انسان

هدفى متصور نيست و سه نوع از مبانى (مبانى عام انسانشناختى، مبانى انسانشناختى مبتنى بر دور هرمنوتيك ميــان افكار، احوال و اعمال و مبانى تربيتدينى)، هدف غايى،

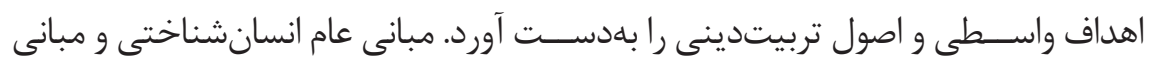
انسانشـــناختى مبتنـى بر دور هرمنوتيكى ميان افكار، احوال و اعمال، در حكمت متعاليه قابل استناد است اما مبانى، اهداف و اصول تربيتدينى، نياز به استنتاج از مبانى مذكور دارد.

\section{يافتلهاى يزوهش}

يافتههاى يزووهش بر دو محور اصلى اســتوار اســت. بخش نخست، تحقيقى فلسفى

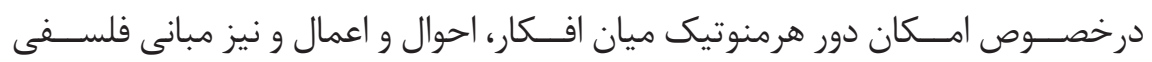

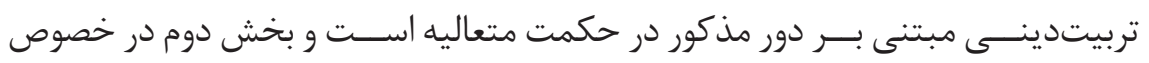
دلالتهاى تربيتدينى از اين مبانى فلسفى است.

\section{مبانى انسان شناختى مبتنى بر دور هرمنوتيكى ميان افكار، احوال و اعمال} ○نأثير مثنقابل افكار و احوال:صدرالدينشيرازى افكار را بر احوال و احوال رابر افكار مؤثر مى داند. همان طور كه حكمت مانع محبت باطل (احوال) و موجب تقوا و زهد (اعمال)

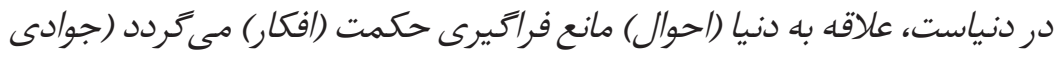

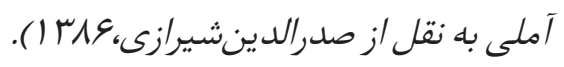

در اين بيان، ابتدا از تأثير افكار بر احوال و احوال بر اعمال و سيس به تأثير احوال بر

$$
\text { افكار سخن مى گويد. }
$$

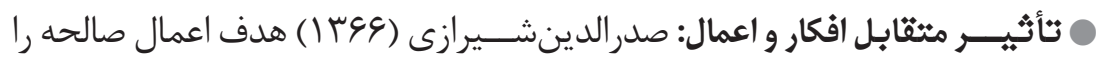
نجات نفس از علائق يســتى مى هاند كه منجر مىشود تا آيينه قلب تيره و مكدر

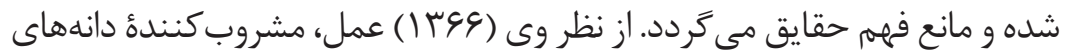

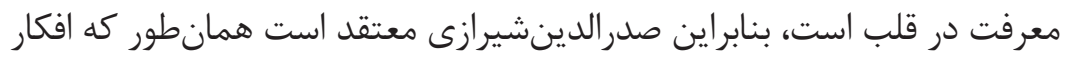




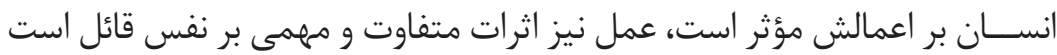

كه يكى از آنها كسب معرفت است؛ و در شواهدالربوبيه (TVD الف) مىنويسد:

نفس هنَخام رسيدن به مرتبعَ كمال عقلى و ببىنيازى از حركات فكرى، دو قوءة

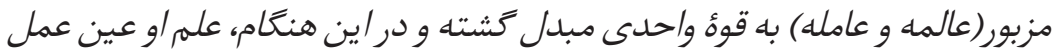

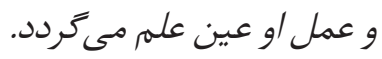

باهر مرحله از رشــد آدمى، فاصلهُ علم و عمل كم شده و تا جايى مىرسد كه از يكى

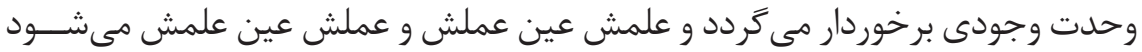

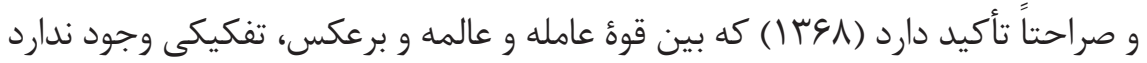
؛ بنابراين همان گونه كه علم، مى تواند منجر به عمل شود؛ عمل نيز مىتواند منجر به علم

$$
\text { شود. عملِ انسانها مى تواند به كسب معرفت منجر شود. }
$$

Oتأثبير مثتابل احوال و اعمال: در نعاه رايج، علوم مقدماتى بر احوال انسان تأثير حذار اســت و نيز احوال آدمى بر اعمال او مؤثرند؛ اما در ادامه صدرالدينشيرازى عقيده دارد ( ا 1 I ) اين اعمالى كه از شناخت اوليه حاصل شد، مجدداً بر احوال او مؤثر بوده و احوال، نيز شناخت جديدى را حاصل مىنمايند. تأثير افكار، احوال و اعمال، در يك سطح باقى نمانده و موجبات رشد انسان را فراهم مىسازد.

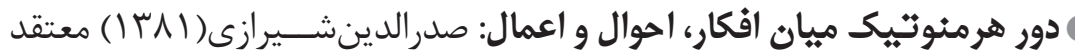
اســت، ظاهربينان و كوتهانديشان و كســانى را كه در اول قدم تفكر درماندهاند، جنين به نظر مى رسد كه علوم، مقدمة احوال و احوال مقدمةٔ اعمال اند و بدين جهت اعمال در نظر آنان برترى دارد، زيرا هدف آخرين است؛ و اما آنان كه بينشى زرف و خميــرهاى نورانى دارند، امر را برعكس اين مى دانند، يعنى اعمال را براى تحوّل احوال و احوال را براى ارتقاى افكار مى خواهند. اين خود بهتنهايى نشـــان مى دهد كـــه همانطور كه افكار بر احوال و احوال بر اعمال تأثير دارد، اعمال نيز بر احوال و احوال بر افكار مؤثر اسـت. صدرالدينشيرازى (و ع ا ) معتقد است اهل ظاهر، شـــناخت را حاصل مى كنـند تا به احوال برسند و احوال را بهدست مى آورند تا به اعمال برســـند؛ اما صدر الدينشيرازى تصريح مى كند كه اهل بصيرت برخلاف اين سير را مى خواهند و اخر دست به عمل ميزنند، براى رسيدن به علم الهى است. وى باهصراحت تأكيد دارد كه اعمال بر احوال و احوال بر افكار مؤثرند. 


\section{$\Delta \mathrm{V}-\wedge \wedge$}

علاوه بر آنجه از صدر الدينشـــيرازى بهطور مســتقيمى نقل شد؛ مىتوان كَفت، تمام اوصافى كه واجبالوجود با ممكن الوجود مشــترك باشــد، وجودى است (جوادى آملى،

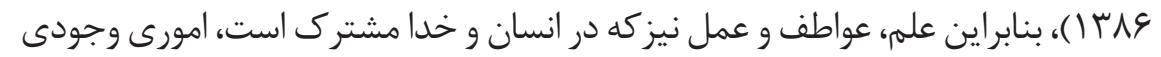
هستند. از طرف ديخر هر ₹اه بِذيريهم كه علم مساوق باوجود است، مى توان اين معادله را بهصورت ديگرى بسط داد كه وجود مساوق با علمه، عاطفه و عمل است؛ جراكه تمام اين اوصاف وجودى هستند و با رشد هر يك از اين مؤلفهها، بايد انتظار رشد مؤلفههاى ديخر را داشت. جيزيكه در اين يزوهش از آن به دور هرمنوتيك ميان افكار، احوال و اعمال ياد مىشـــود. در اين دور، رشد انسان بهقدرى بالا مىرود كه علم او با عملش يكى مى شود. نمودار r دور هرمنوتيك ميان افكار، احوال و اعمال را بهصورت خلاصه نمايش مى بـهد.

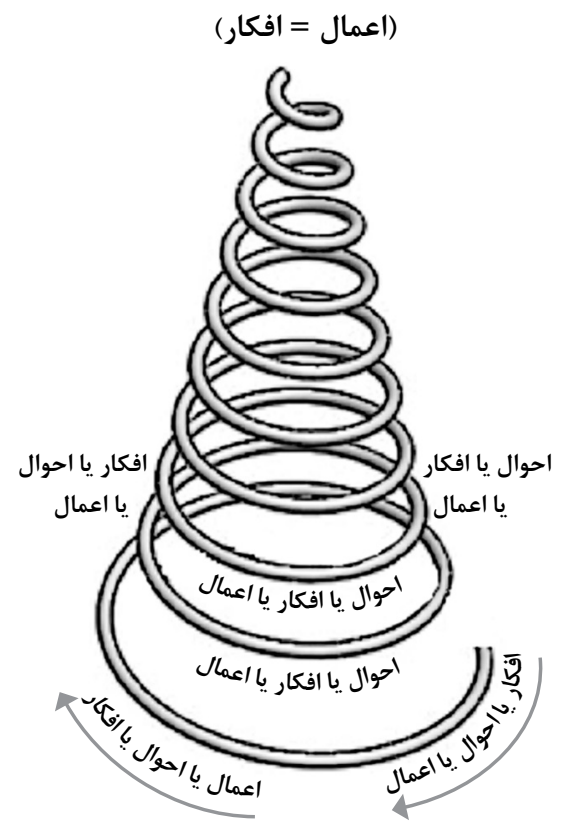

نمودار ז. دور هرمنوتيك ميان افكار، احوال و اعمال در حكمت متعاليه

\section{مبانى تربيت}

همان گَونه كه حذشت صدرالدينشــيرازى فيلسوف تعليم و تربيت نيست، بنابراين، اهداف و اصول تربيتى را مىبايســت از مبانى فلسفى وى استنتاج نمود. اكنون با تعميم 
مى توان مبانى تربيتدينى مبتنى بر دور هرمنوتيك را بهصورت زير بيان نمود:

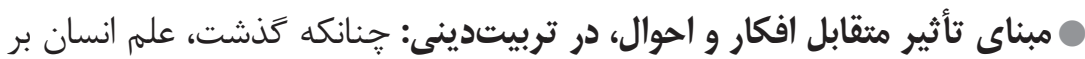
احوالش مؤثر است. اين علم و احوال در تمام ساحتها از جمله در ساحت باورهاو انخيزههاى دينى مطرح است؛ براين اساس، مى توان از تأثير افكار و باورهاى دينى در احوال و احساسات دينى و استنتاج اصول تربيتدينى استفاده نمود؛ بنابراين مى توان جُنين نتيجه گرفت كه اافكار و باورهاى دينى انسان در احوال و عواطف دينى او مؤثر است." همجنين در مبناى انسانشناختى مبتنى بر دور هرمنوتيك ميان افكار، احوال و اعمال، تأثير احوال بر افكار بررسى شد كه نشان مى دهد در معادلات وجودى انسان، علاوه بر آنكه شناختها و افكار انسان بر احوالش مؤثرند، احوال و احساسات و عواطف انسانى نيز، در كسب شناختها و افكار جديد نقش يكسان، همسنگ و هموزن دارند. بديهى است با توجه به مبناى موردبحث، درصورتى كه احساسات و عواطف و احوال انسان مورد تحريك و تهييج قرار گيرند، افكار، باورها و شناختهاى انسان نيز بلهتبع آن مورد تحوّل قرار مى گيرند و نيز درصورتى كه عواطف دينى انسان تحريك شود، اين تغيير احوال، به تغيير شناختها و باورهاى دينى نيز منجر خواهد شد و اين ارتقاى افكار كمك به مسير الهى شدن انسان مىنمايد؛ بنابراين مى توان جنين نتيجه گرفت كه 》احوال دينى انسان بر افكارش در سير الى الله مؤثر است. مبناى تأثير متقابل احوال و اعمال، در تربيتدينى: هرگونه تغيير احوال منجر بهايجاد اعمالى متناسب با آن احوال خواهد شد؛ بنابراين در عرصة احوال دينى در منظومة تربيتدينى نيز اين امر قابلتعميهم است، گ بس در وجود آدمى تغيير هرگونه احوال دينى منجر به انجام اعمال دينى خواهد شد و اعمال دينى(انجام واجبات و مستحبات و نوافل) در نزديكى به خداوند تأثير دارد؛ بنابراين ا|حوال دينى بر اعمال انسان در قرب به خداوند متعال مؤثرند." همجنين همان گَونه كه گذشت در حكمت متعاليه، اعمال انسان بر احوالش تأثير كذار است. اين امر مخالف نغاه و رويكرد خطى و يك جانبه است كه تاكنون طرفداران بسيارى در بين حكما داشته و دارد. در تربيتدينى، درصورتى كه اعمال دينى از انسان سربزند، اين اعمال منجر به تغيير احوال، احساسات و عواطف دينى خواهد شد؛ بنابراين

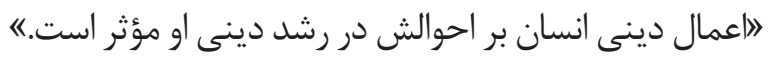

○مناى تأثير متقابل افكار و اعمال، در خدايى شدن: نهتنها در حكمت متعاليه، بلكه نظر بيشتر حكما بر اين مبنا استوار است كه افكار آدمى، منجر به توليد اعمال جديدى مئى 


\section{$\Delta v-\wedge \Lambda$}

مى گردد. از اين امر مورد اجماع مىتوان در تربيتدينى نيز استفاده نمود كه كسب باورهاى دينى، منجر بهايجاد و انجام اعمال دينى خواهند شد. انجام اعمال دينى به انسان درراه

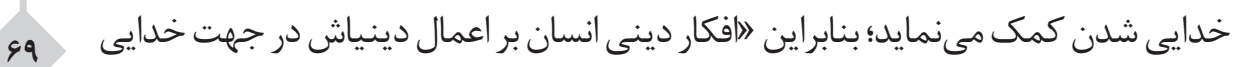
شدن مؤثر است." همجٍنين باتوجه به آنجه حَذشت، در حكمت متعاليه، اعمال انسان باعث كسب باورها، علوم و شناختهاى جديد ميگردند. در عرصه تربيتدينى از اين مبنا مىتوان استفاده كرد تا با استنتاج اصول و روشهاى تربيتدينى در ارتقاى انسان در مباحث دينى و درنتيجه در تشبه او به خداوند سبحان در اسما و صفات استفاده نمود؛ بنابراين مىتوان جنين نتيجه گرفت كه \اعمال دينى انسان بر افكار دينى او در تشبه به خدا مؤثر استها. مبناى تأثير و تأثر تمام قوا بريكديگر (دور هرمنوتيك) در تربيت دينى: باتوجه به مبناى دور هرمنوتيك ميان افكار، احوال و اعمال در حكمت متعاليه، مىتوان اين مبنا را به تربيتدينى نيز تعميهم داد و اين گونه نتيجه گيرى كرد كه با وجود تعدد قواى انسان، اين قوا در برهم كنشى دائمى و هموزن هستند. با تغيير يكى از قوا، قواى ديخر نيز تغيير خواهندكرد و اگر اين تغيير در جهت تربيتدينى باشد، ارتقاى تمام قوا در اين زمينه خواهد بود؛ بنابراين اهميت دادن به تمام قوا و حركت به سمت نگاه جامع در تربيتدينى امرى لازم است و تمام قوا بريكديخر در تربيتدينى مؤثرند.

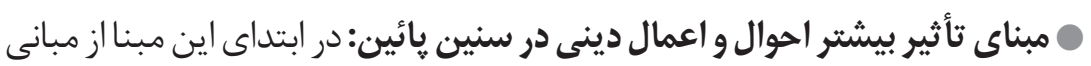
تربيتدينى، ذكر هُند نكته ضرورى به نظر ميىرسد: (. از نظر صدرالدينشــيرازى انســان در سير تكاملى خود داراى سه نشئه وجودى

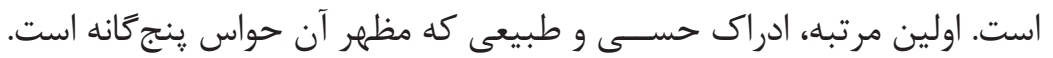

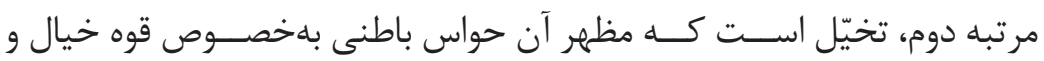

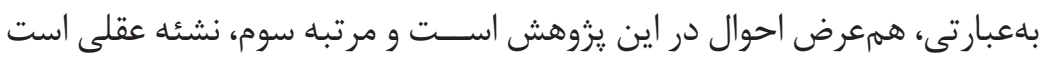

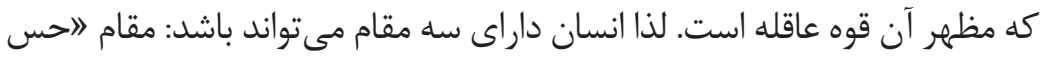

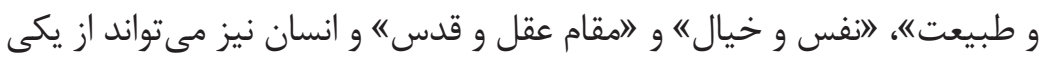
از اين سه وجود برخوردار باشد: انسان حسى كه متشكل از جسد اوست و فنايذير، انسان نفسى (برزخى) كه جون مجرد از ماده است، فنانايذير است و انسان عقلى جلى كه ثابت اسـت و كمال انسانيت انسان به آن وابسته است. براساس اين مقين مقياس، 


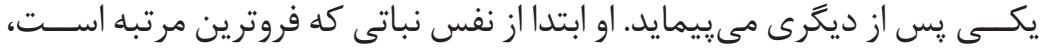

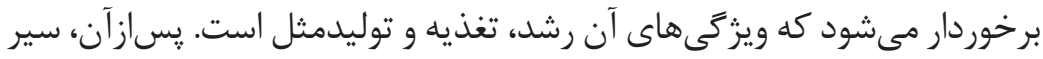
حركت جوهرى ادامه يافته و او از مرحله نفس حيوانى بهرهمند مىشود. احساس و حركت از خصوصيات اين مرحله اسـت. سيس، به مرتبه اشرف و نفس ناطقه دســت مىيابد كه علم و آكَاهى از مختصات آن است. اين مرتبه، موازى با عالم

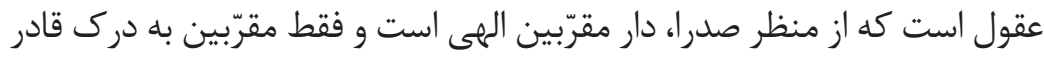
خواهند بود. در نظر صدرالدينشــيرازى، انسان در هر مرحلهاى به فراخور همان

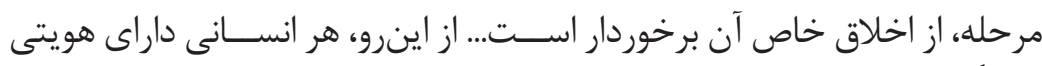

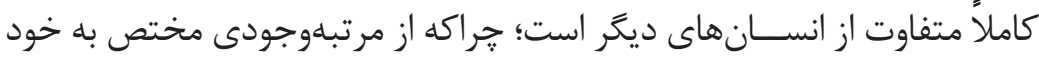
برخوردار اســت (ديرباز، دهقان سيمكانى، هوس ())؛ بنابراين انسان براى رسيدن

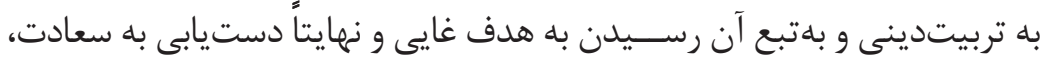
بايد از سيهر اعمال و احوال عذشته تا به جهان عقلانى و تربيت مخصوص به به به آن دســت يابد؛ لذا براى تربيت شدن، در هر نشئه بايد به مؤلفههاى مهرمه آن نشئه

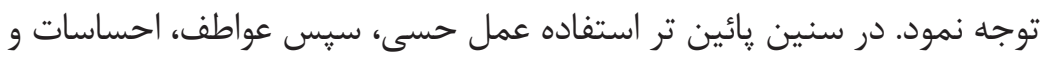
احوال و در مرحله بعد، شناختهاى عقلانى.

همجزنين از ســـمت ديخر و با توجه به مبناى رابطهُ انديشـــه و احساســات در

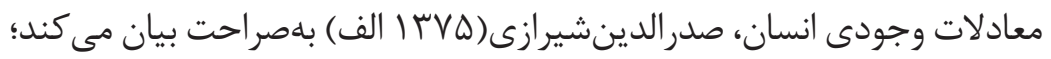
كمال قوه حساسيه كه مساوق با محركه است موجب تأثير در مواد جسمانيه و

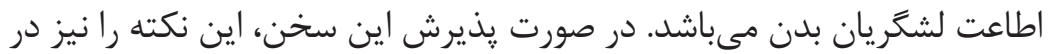

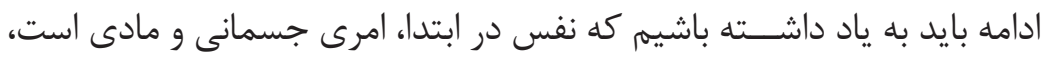
يس از ادراكها و كسب شناختها بلتدريج، حالت روحانى به خود ميى

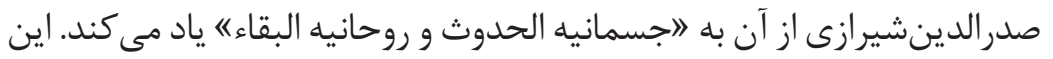

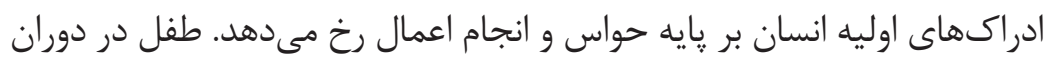
اوليه زندگى خود به كمك قدرت حواس، با لمس، بوئيدن و جشـــــن غذاها و شنيدن صداهاى مختلف به شناختهاى جزئى دست مي ريابد. همجنين وى (UVW الف) تصريح مى كند، قواى حساسه مساوق با محر كه است و بر ساير

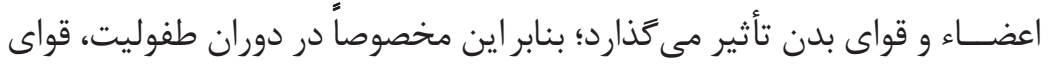
عامله و محر كه (احوال) بر نفس و قواى آن منجمله عقل، تأثير گذار است. 


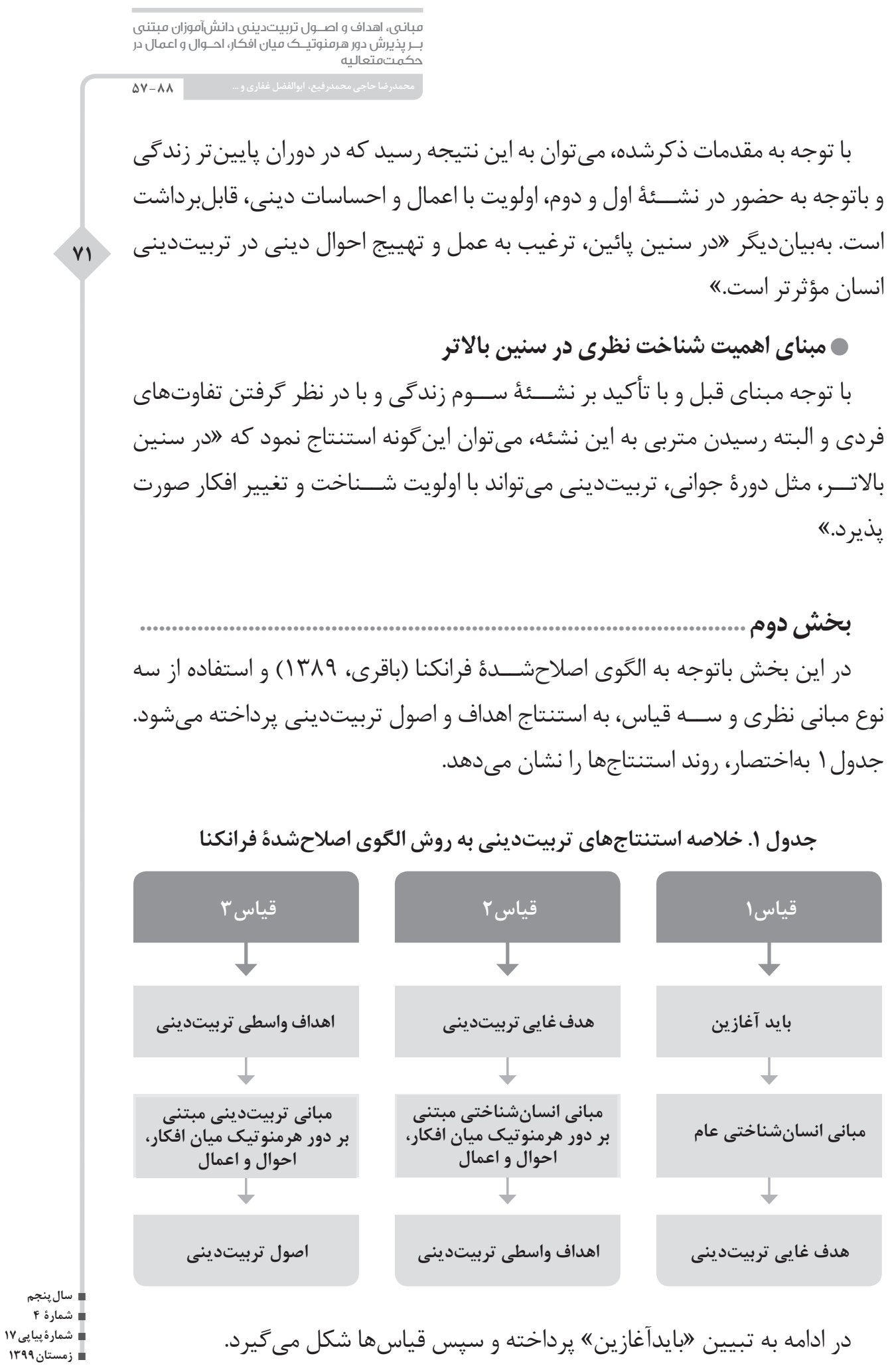




\section{بايد حياتى}

بايـــد حياتى، ززارهاى هنجارين اســت كه بيانكر حال انســان و مبتنى بر ضرورت

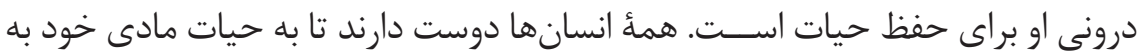

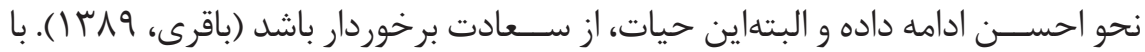
توجه به مبناى رابطةُ رشد عقلانى و تعالى سعادت بشر؛ هر انسانى دنبال سعادت يعنى كمال، خير و لذت اســت. از منظر صدر الدينشيرازى رسيدن به سعادت، بالاترين هدف

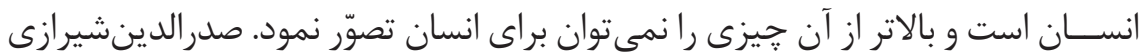

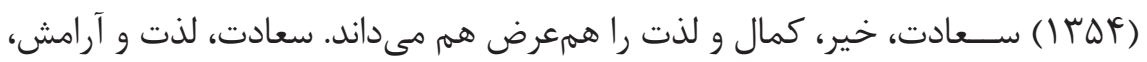

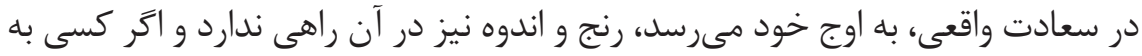
دنبال سعادت واقعى نرود، دجار درد و رنج و اندوه مىشود كه بسيار سخت تهر و شديدتر

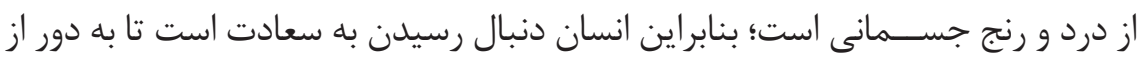
درد و رنج و اندوه به سر ببرد.

\section{○ استنتاج هدف غايى تربيتدينى}

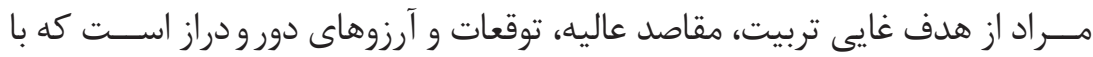
ديدى خوشبينانه نســبت به آينده بوده و در قالب جمــلات و اصطلاحات كلى مطرح مى گردد. هدف غايى كاهى از سنتهاى اجتماعى، خواه دينى و خواه غيردينى سر جشهمه

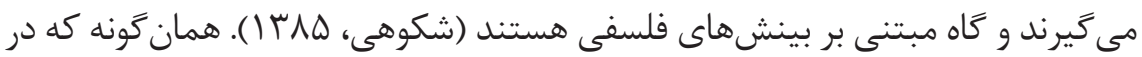

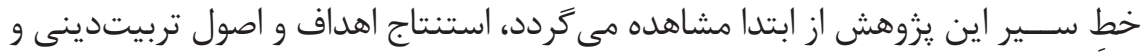

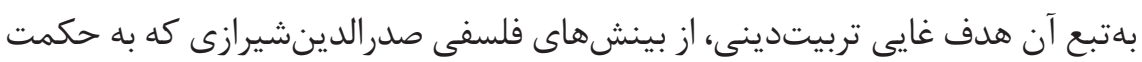

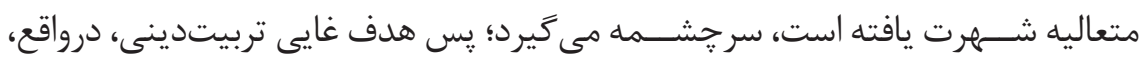
جشـهمانداز نهايى و گزارهاى انشايى است كه حاوى مفهوم لابايد" بوده و تمام تلاشهاى

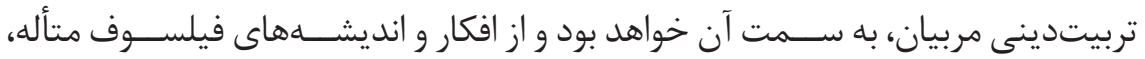
صدر الدينشيرازى استنتاج مى كردد.

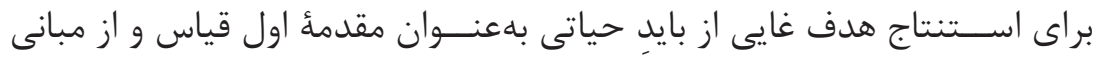

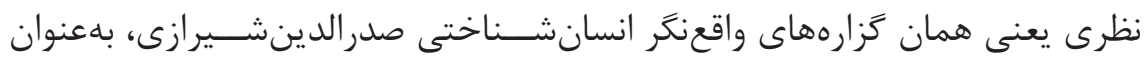

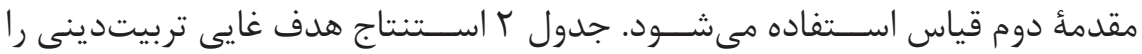




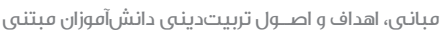

\section{جدول r. استنتاج هدف غايى تربيتدينى}

\begin{tabular}{|c|c|}
\hline ه انسان مى خواهد زندگى سعادتمندى داشته باشد. & (تزاره مقدمه اول: \\
\hline 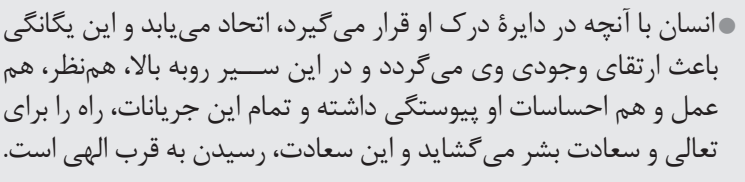 & 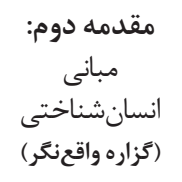 \\
\hline 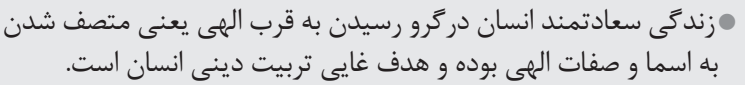 & نتيجه \\
\hline
\end{tabular}

با توجه به قياس بالا كه انسان مى خواهد زندگى سعادتمندى داشته باشد، بهعنوان

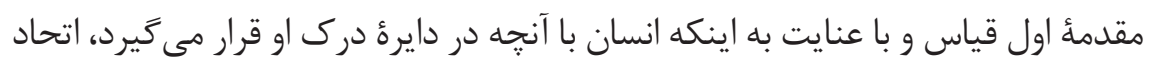
مىيابد (اتحاد عاقل و معقول) و اين يخانكى باعث ارتقاى وجودى وى مى گردد (مساوقت وجود با علم) و در اين ســير رو به بالا، همنظر، همى عمل و هم احساســات او (رابطة نظر

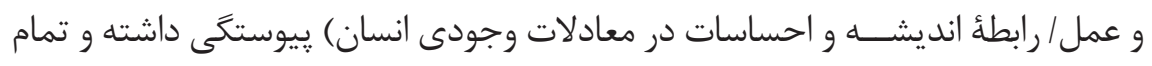
اين جريانات، راه را براى تعالى و ســعادت بشر ميخشايد و اين سعادت، رسيدن به قرب الهى است(رابطهُ رشد عقلانى و تعالى سعادت بشر)، بهعنوان مقدمهُ دوم قياس؛ مى تى توان

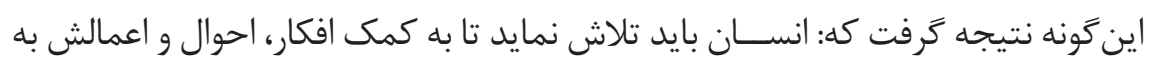

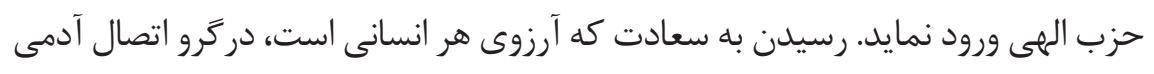

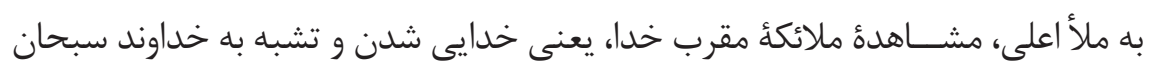

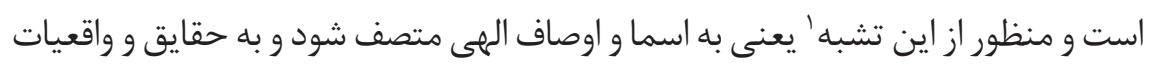

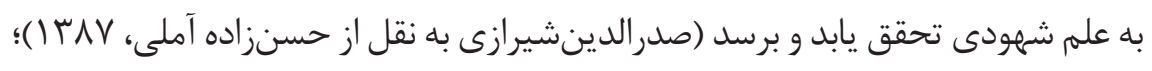
اين آخرين هدف و بلهبيانديخر هدف غايى از يك نظام تربيتدينى مى تواند باشد.

\section{ماستنتاج الهداف واسطى تربيتدينى}

اهداف واسطى نسبت به هدف غايى، دامنه كوتاهترى داشته و جار جوب كلى براى رسيدن

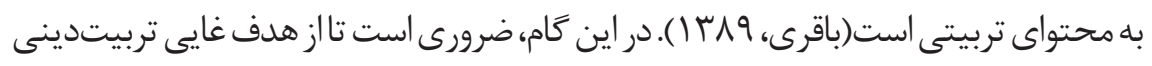


كه گَزارهاى هنجارين و حاوى مفهوم لابايده اسـتـ و نيز مبانى انسانشــناختى مبتنى بر دور هرمنوتيكى ميان افكار، احوال و اعمال كه گَزارهاى واقعنخر و حاوى مفهوم لاســت مىباشد، بهعنوان مقدمات قياس استفاده نمود تا اهداف واسطى تربيتدينى، استنتاج گردد.

$$
\text { هدف واسطى اول: دستيابى به افكار و احوال دينى }
$$

با توجه به قياسى كه در جدول ب نشان دادهشده است، هدف واسطى اول استنتاج مى

\section{جدول r. هدف واسطى اول تربيتدينى}

برسد. بان بايد به اسما و صفات الهى متصف شود و به مقام عبوديت

• افكار و احوال انسان بر يكديكر تأثير دارند.

•بايد به افكار و احوال دينى كه انسان را خدايى مى كند بيردازد.

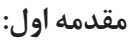

هدف غايى تربيت دينى

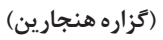

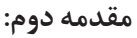

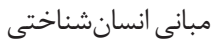

مبتنى بر دورهرمنوتيك أسنى

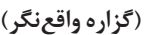

نتيجه

باتوجه به استنتاج فوق، هدف واسطى اول، اهميت دادن به افكار و احوالى است كه در خدايى شدن و عبد شدن انسان بهعنوان نهايت هدف تربيتدينى مؤثر است.

$$
\text { هدف واسطى دوم: دستيابى به احوال و اعمال دينى }
$$

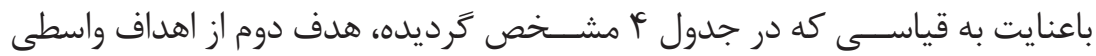

$$
\text { استنتاج مى گردد. }
$$

\section{جدول F. هدف واسطى دوم تربيتدينى}

•انســان بايد به اسما و صفات الهى متصف شود و به مقام عبوديت برسد.

ماحوال و اعمال انسان بر يكديگر تأثير دارند.

•بايد به احوال و اعمال دينى براى خدايى شدن بيردازد.

\section{مقدمه اول:}

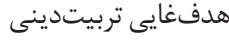

(تزاره هنجارين)

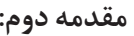

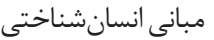

مبتنى بر دورهرمنوتيك انتئي

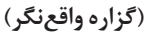

نتيجه 


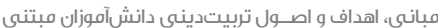

$\Delta \mathrm{V}-\Lambda \wedge$

باتوجه به استنتاج فوق، هدف واسطى دوم، اهميت دادن به احوال و اعمالى است كه در خدايى شدن و عبد شدن انسان در تربيتدينى مؤثر است. > هدف واسطى سوم: دستيابى به اعمال و افكار دينى در جدوله استنتاج هدف واسطى سوم نشان دادهده است. جدوله. هدف واسطى سوم تربيتدينى

• انسان بايد به اسما و صفات الهى متصف شود و به مقام عبوديت برسد.

•اعمال و افكار انسان بر يكديخر تأثير دارند.

هبايد به اعمال و افكار دينى براى خدايى شدن بيردازد.
مقدمه اول:

هدف غايى تربيتدينى

(كزاره هنجارين) (كائ)

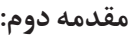

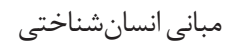

مبتنى بر دورهرمنوتيك انسئ

(كزاره واقع نتخر)

نتيجه

باتوجه به استنتاج فوق، هدف واسطى سوم، اهميت دادن به اعمال و افكارى است كه در خدايى شدن و عبد شدن انسان مؤثر است. > هدف واسطى جههارم: دستيابى توأمان به افكار، احوال و اعمال دينى در قياس جدول ع استنتاج هدف واسطى جهارم نشان دادهده است. جدول 9. هدف واسطى جهمارم تربيتدينى

هانسان بايد به اسما و صفات الهى متصف شود و به مقام عبوديت برسد.

$$
\text { •دورهرمنوتيك ميان افكار، احوال و اعمال }
$$

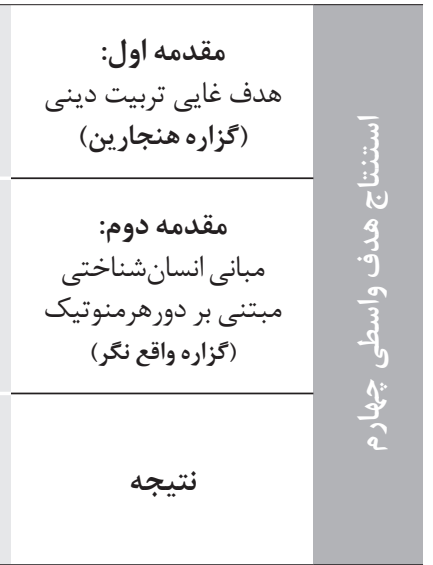


باتوجه به استنتاج فوق، ا|تصال به ملأ اعلى، مشاهدة ملائكة مقرب خداوند و خدايى شدن (تشبه به بارىتعالى در اسما و صفات)《 بهعنوان مقدمةٔ اول و \تأثير متقابل احوال و افـكار، اعمال و احوال، اعمال و افكار و دور هرمنوتيك افكار، احوال و اعماله بهعنوان مقدمة دوم قياس اين نتيجه را مىدهد كه براى خدايى شدن بايد، بهدستيابى توأمان و بى توجهى نكردن به هريك از سه مؤلفهُ افكار، احوال و اعمالى كه انسان راخدايى مى كنند يرداخت؛ به ديخر سخن بايد به تربيتى جامعنگر و كُلنگر در تربيتدينى يرداخت. بهطور خلاصه، اهداف واسطى تربيتدينى در جدول V نشان داده مىشود.

\section{جدول V. استنتاج اهداف واسطى تربيتدينى}

\begin{tabular}{|c|c|c|}
\hline بر انســـان بايد به اسما و صفات الهى متصف شود و به مقام عبوديت & 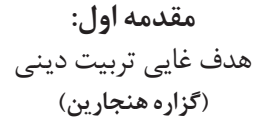 & \\
\hline 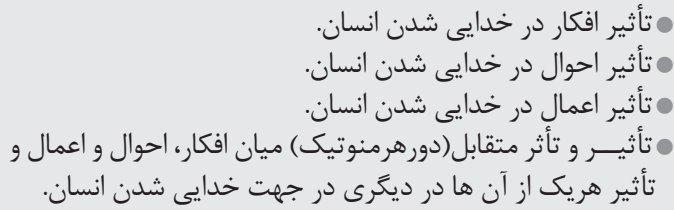 & 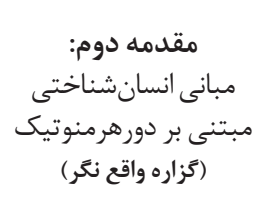 & $\frac{\frac{3}{3}}{\frac{3}{3}}$ \\
\hline 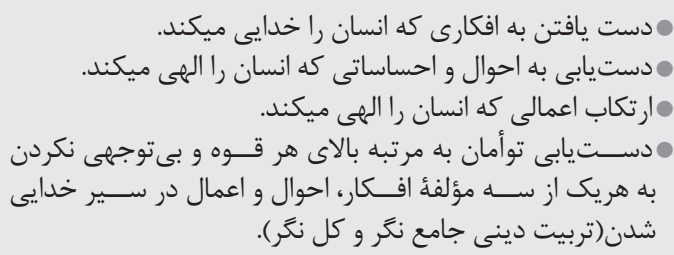 & نتيجه & 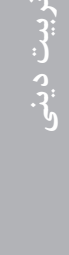 \\
\hline
\end{tabular}

\section{ماستنتاج اصول تربيتدينى}

در اين مرحله لازم اســت تا در قياســى كه از اهداف واسطى بهعنوان مقدمه اول و مبانى تربيتدينى مبتنى بر دور هرمنوتيك ميان افكار، احوال و اعمال، بهعنوان مقدمءٔ دوم شكل مى گيرد، به اصول تربيتدينى دستيافت. قبلا تذكر اين نكته ضرورى بهنظر مىرسد كه با توجه به ادعاى اصلى يزوهش كه رسيدن به تربيتى جامعنگً است، بخش بخش كردن اصول مطرحشده، از جنبهُ نظرى يزوهش بوده و به جهت روشنگرى بيشتر بحث است. جدول 1 نحوء استنتاجهاى اصول را نشان مى نهد. 


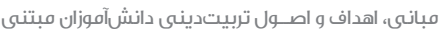

\section{جدول^ه. استنتاجهاى اصول تربيتدينى}

\begin{tabular}{|c|c|}
\hline هدف هدماره واسطى & \\
\hline مبانى تربيت دودينى & \\
\hline نتيجه & \\
\hline
\end{tabular}

\section{هـ اصل تغيير افكار دينى بلمنظور تحوّل در احوال دينى و تحوّل در احوال دينى براى} تغيير در افكار دينى

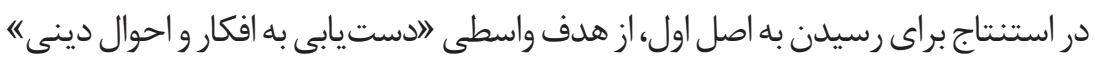

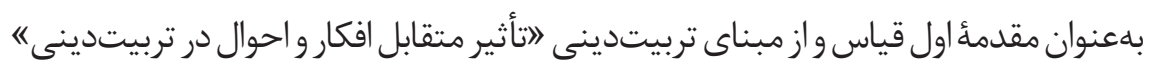

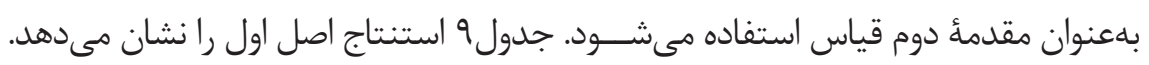
جدوله. استنتاج اصل اول تربيتدينى

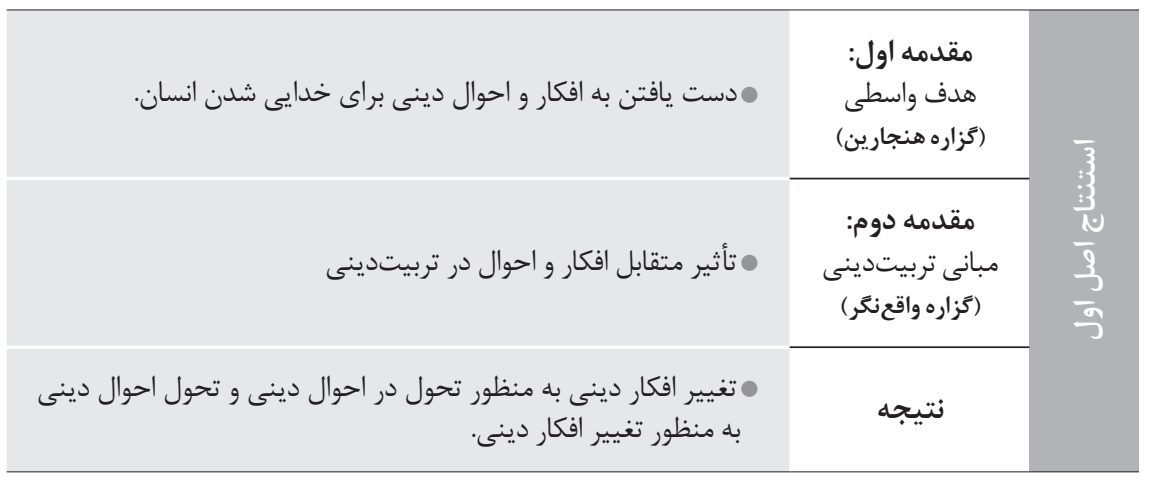

بــا توجه به قياس فوق، مىتوان اين اصل تربيتى را اســتنتـاج نمود كه درصورتى كه

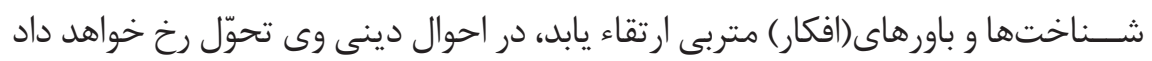

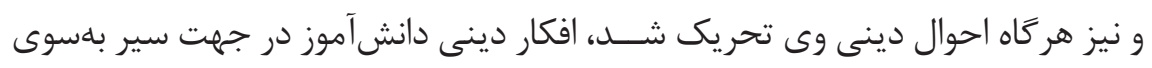

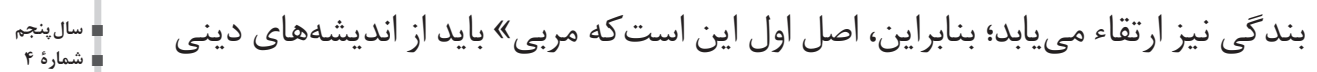

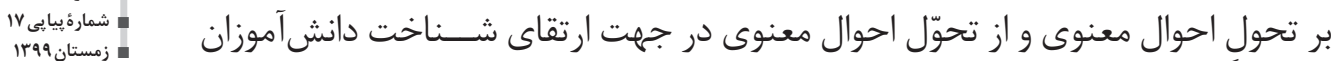


خود اســتفاده نمايد.《 لذا اســتفاده از علوم توليدى، اعم از هنر، ادبيات، داستان، رمان و تمثيل كه هم داراى وجه معرفت افزايى و هم وجه تهييج عواطف است مىتواند موردنظر

اصل تحوّل در احوال دينى براى انجام اعمال و ارتكاب اعمال دينى بهمنظور تحريك

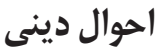

در استنتاج براى رسيدن به اصل دوم، از اهداف واسطى" دستيابى به احوال و اعمال

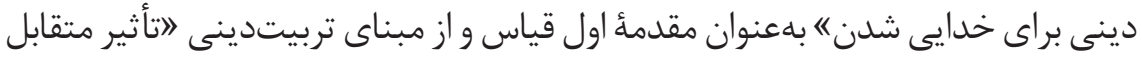
احوال و اعمال در تربيتدينى" بهعنوان مقدمة دوم قياس اســتفاده مىشود. جدول هـ 1

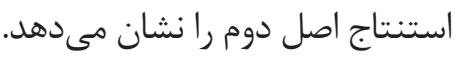

جدولها. استنتاج اصل دوم تربيتدينى

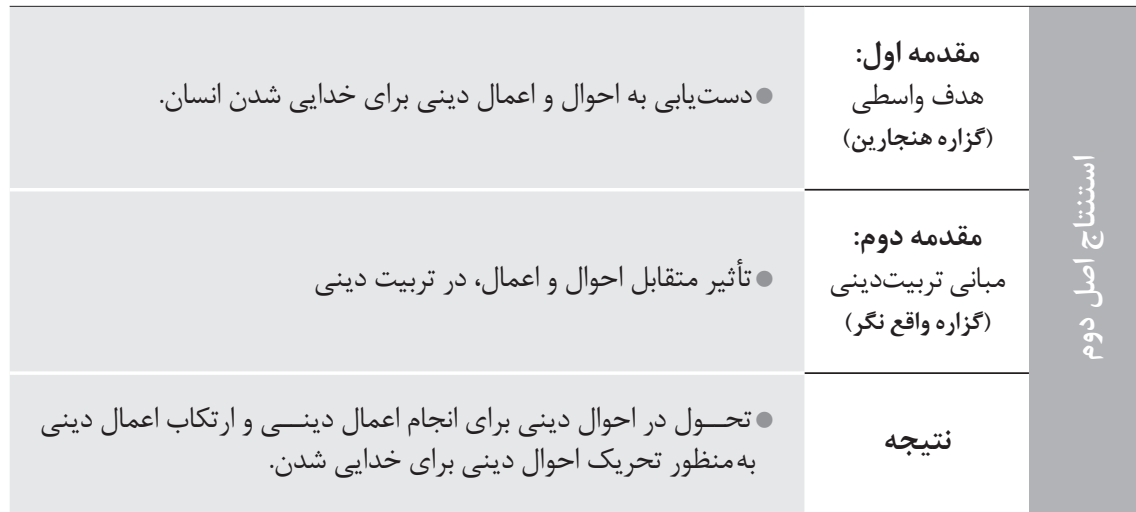

بنابراين مىتوان اين نتيجه را دريافت نمود كه در صورت تغيير احوال دينى دانشآموز

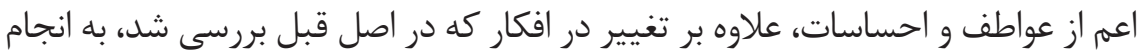

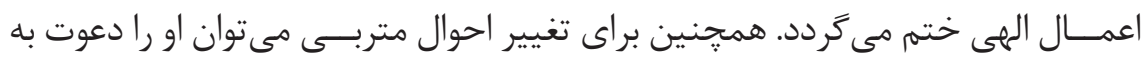
اعمال دينى نمود، در اين خصوص مىتوان از روشهايى جون عادت دادن، تلقين كردن و ترغيب نمودن نيز استفاده كنند؛ بنابر اين، اصل دوم اينكونه خواهد بود كه مربى ابايد

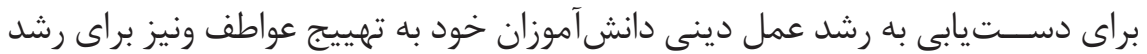

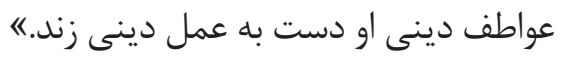




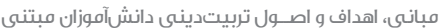

\section{$\Delta \mathrm{V}-\Lambda \Lambda$}

\section{•ـ اصل انجام اعمـال ديــى بلمنظور تـغيير افكار دينى و تغيير افكار دينى براى انجام

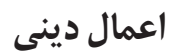

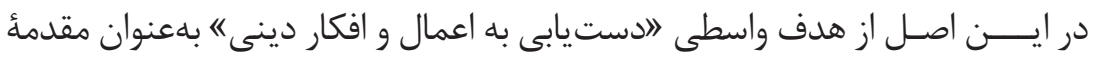

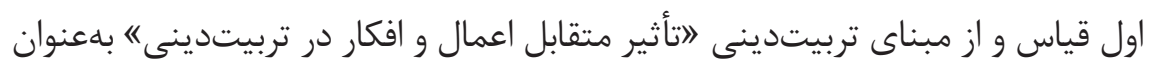

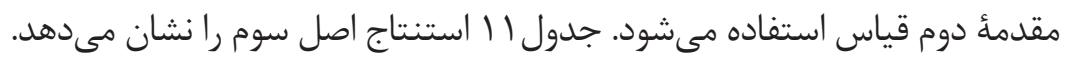

جدول ||. استنتاج اصل سوم تربيتدينى

\begin{tabular}{|c|c|}
\hline ه دستيابى به اعمال و افكار دينى. & هدف مقدمه اول: \\
\hline ه تأثير متقابل افكار و اعمال، در خدايى شدن انسان. & مبانى تربيت مقدينى دوم: مَّر \\
\hline هانجام اعمال دينــى بلمنظظور تغيير افكار دينى و تغيير افكار دينى براى & نتيجه \\
\hline
\end{tabular}

باتوجه به قياس بالا اعمال دينى انسان در شناختها و باورهاى دينى او تغيير ايجاد

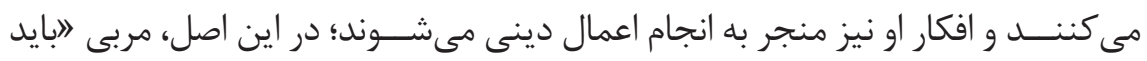

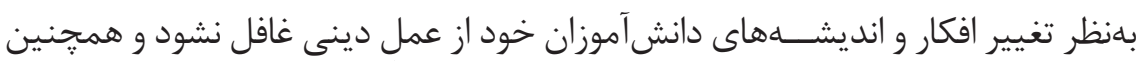

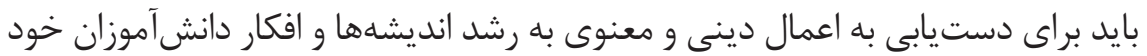

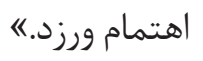

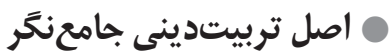

در اين اصل، از هدف واســطى لادســــيابى توأمان به مرتبه بـــالاى هر قوه و عدم

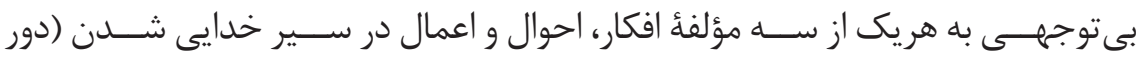
هرمنوتيـك ميان افكار، احوال و اعمال)" بهعنوان مقدمة اول قياس و واتأثير و تأثر تمام

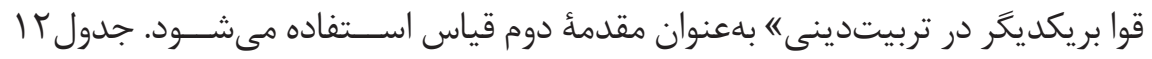


جدول rا. استنتاج اصل جههارم تربيتدينى

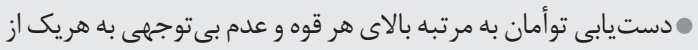

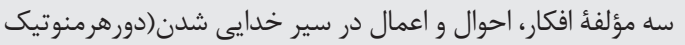

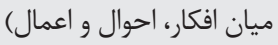

$$
\begin{aligned}
& \text { ه تأثير و تأثر تمام قوا بريكديكر در تربيت دينى. } \\
& \text { •رسيدن به تربيت دينى جامع نكر (استفاده از تمام قوا) }
\end{aligned}
$$

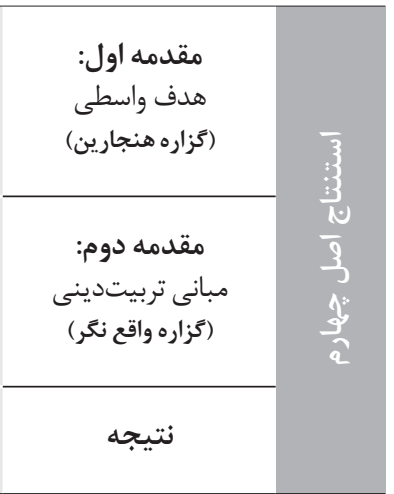

با توجه به قياس فوق، اصل توجه به تربيتدينى جامعنگر استنتاج مى گردد. با توجه به اين اصل، مربى ابايد از تمام ساحتهاى متربى درجهت رشد تربيتدينى او و رسيدن بله تربيتدينى جامعنغر استفاده نمايد.ب

\section{هـ اصل اولويت در ترغيب به اعمال و تهييج احوال دينى در كودكى و نوجوانى}

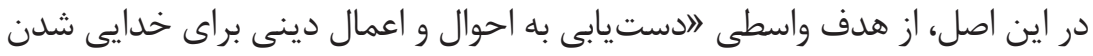

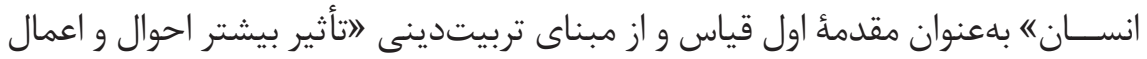

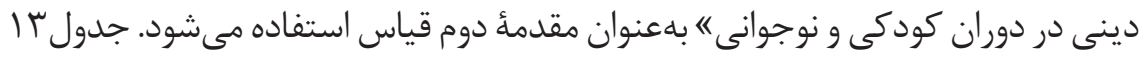

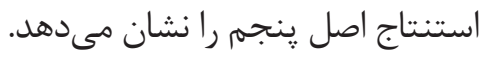

\section{جدول זו. استنتاج اصل ينجم تربيتدينى}

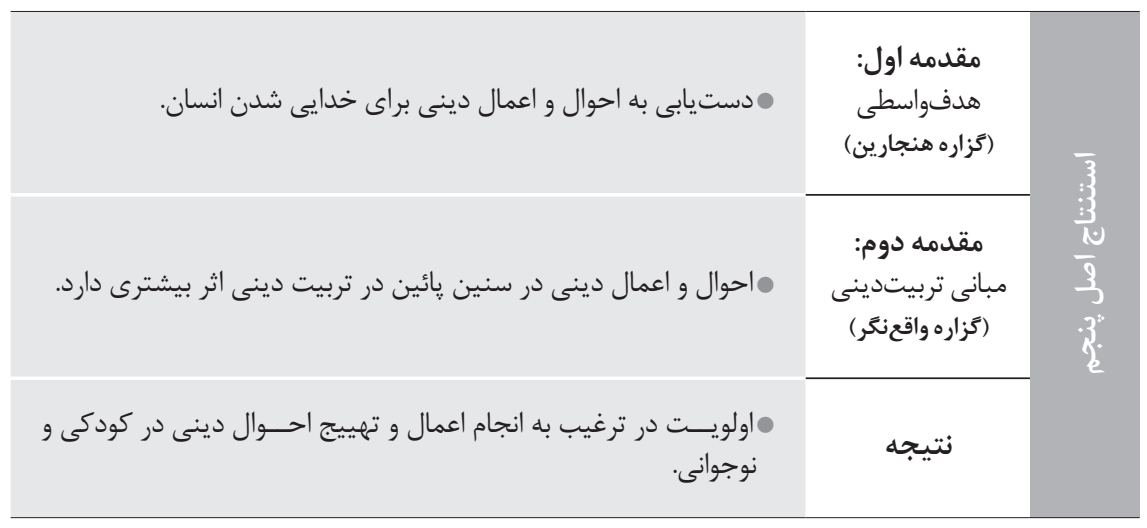




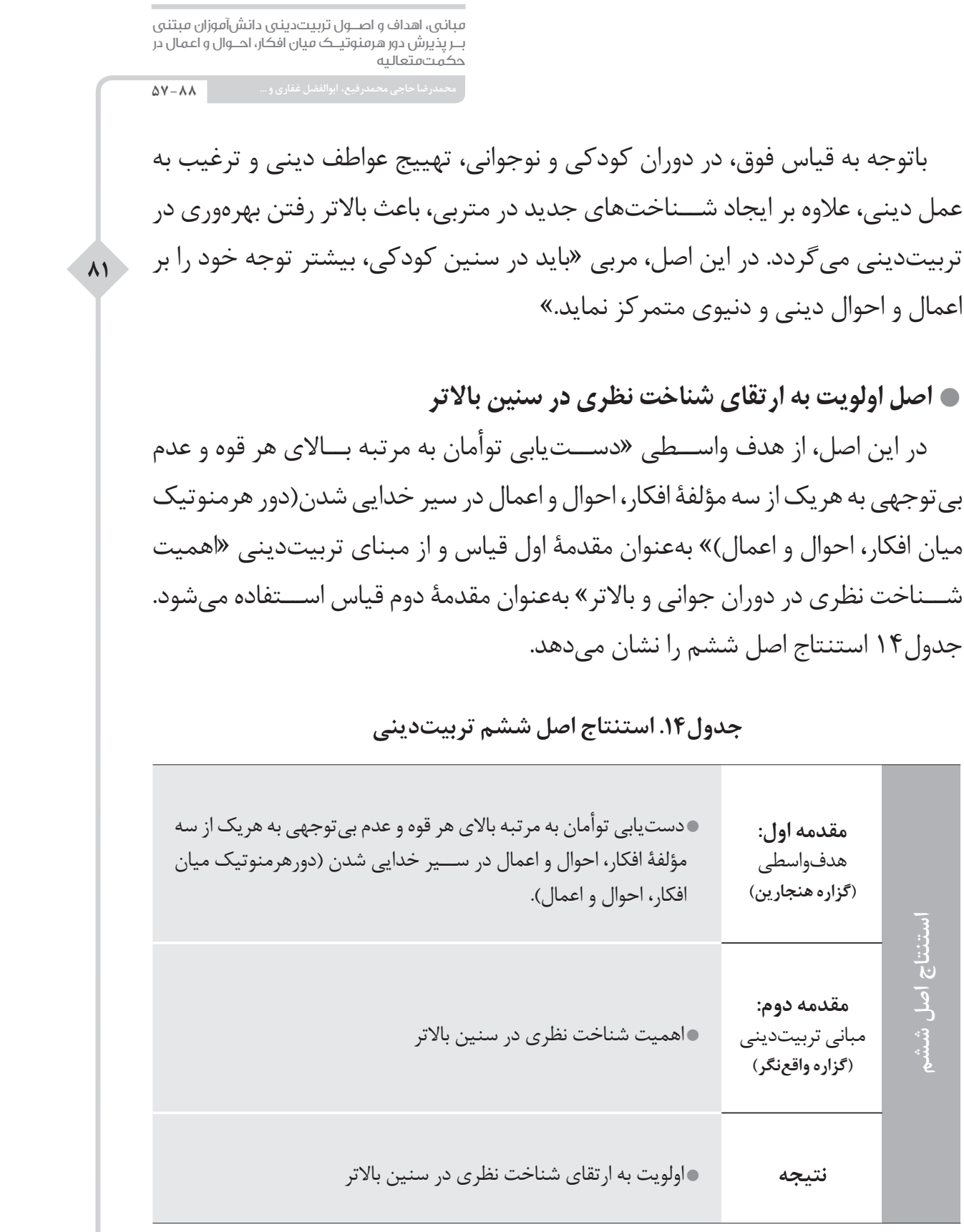

بنابراين مىتوان اصل تربيتى را بر اين يايه بنا نهاد كه مربى الايد براى دستيابى به إبه

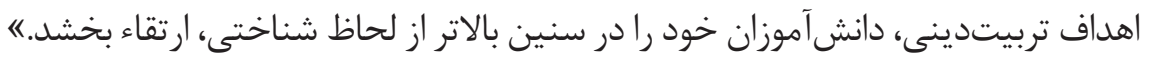

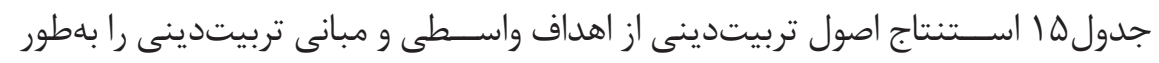
مختصر نشان مى دهد. 
جدول ا. استنتاج اصول تربيتدينى

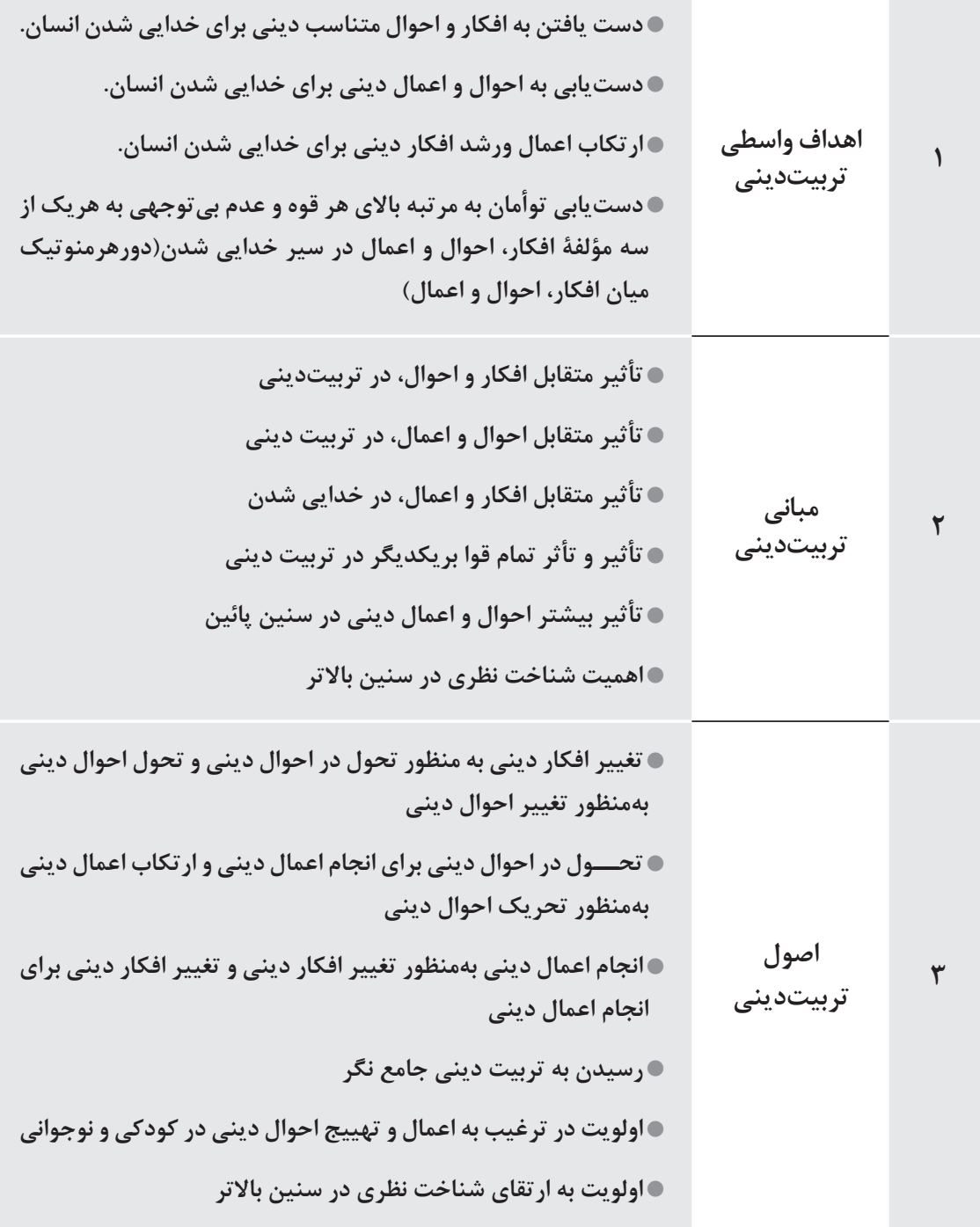

$$
\text { ارتكاب اعمال ورشد افكار دينى براى خدايى شدن انسان. }
$$

هدستيابى توأمان به مرتبه بالاى هر قوه و عدم بـىتوجهى به هريك از اهداف واسطى تربيتدين 


\section{$\Delta V-\wedge \wedge$}

فيلسوفى وحدت گر است كه يكجانبهَر ايى را برنمى تابد و ثانياً قائل به تأثير و تأثر متقابل

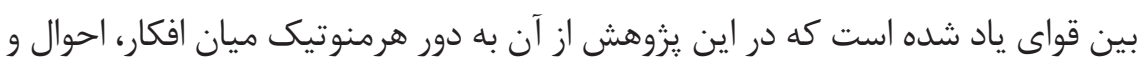

يزوهش هايى كه در گذشته مورد بررسـى قرار گرفته است با بخش هايى از يزوهش

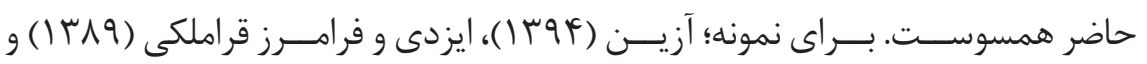

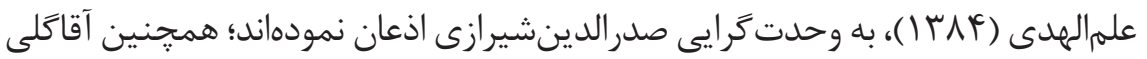

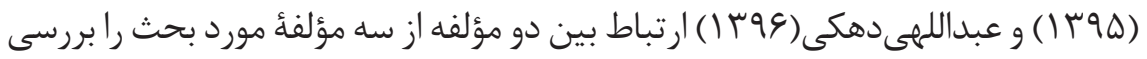
و نتيجهُ تأثير و تأثر متقابل را دريافت نمودهاند كه با اين يزوهش همسو است؛ لكن نكتأ بـ

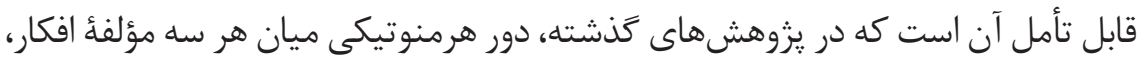

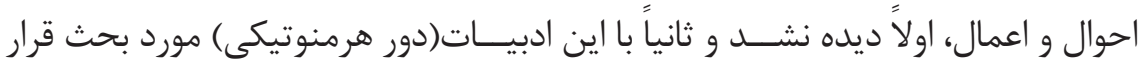
نخرفته|ند.

هدف دوم اين مقاله كه بحث كاربردى آن در نظام تعليم و تربيترســمى مىباشد، دســتيابى به دلالتهاى تربيتدينى از اين نكاه فلسفى جديد است. با رويكرد جديد،

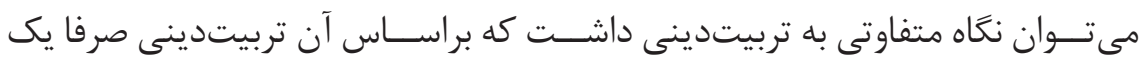
كلاس نظرى و در كنار سـاير كلاسهاى ديخر نيست، جراكه تربيتدينى، تربيتى در كنار ديخر ســاحتهاى تربيت نبوده بلكه تمام شئونات و قوا و ساحتهاى انسانى اعم

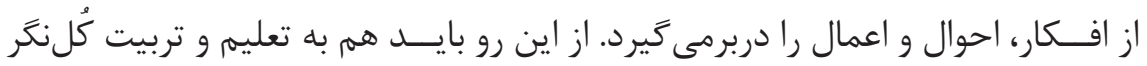
يرداخــت و در يكجانبه گرايى و يرداختن صرف به معرفت افزايى در قالب كلاسهاى نظرى، تجديدنظر نمود. اين تعريــف جديد از تربيتدينى با برخى از يثروهشها مانند

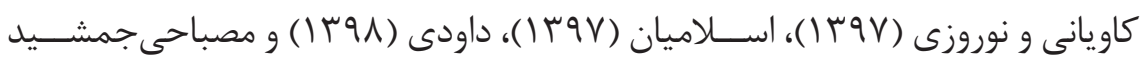

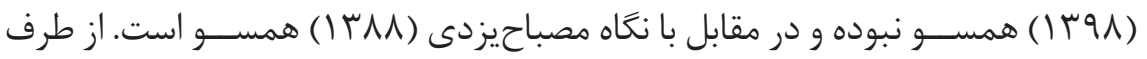
ديخر توجه به تمام قواى دانشآموزان در تربيتدينى و اهميت دادن به احوال و اعمال در كنار افكار، تا حدودى در يزوهش كاويانى و نوروزى (I I ( ) مشاهده شد كه البته خارج از بستر حكمت متعاليه انجام گرفته بود. نكتهٔ حائز اهميت اين است كه تفكيك قوا در مباحث مبانى، اهداف و اصول تربيتدينى در اين :زروهش از جنبةٌ مطالعاتى و نظرى قابل بحث است؛ بنابراين اهم اصول كاربردى 


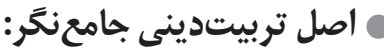

بلموجب اين اصل، با تغيير يكى از مؤلفههاى وجودى دانش آموز اعم از افكار، احوال

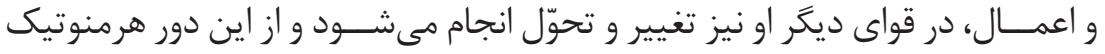

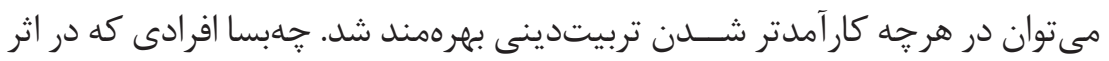

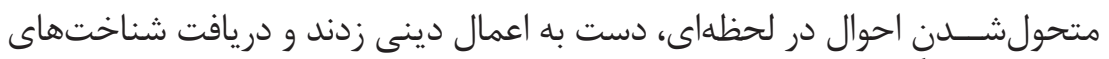

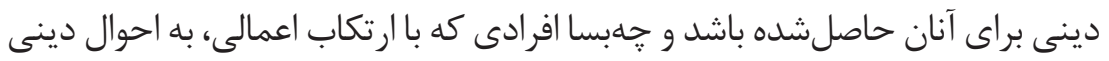

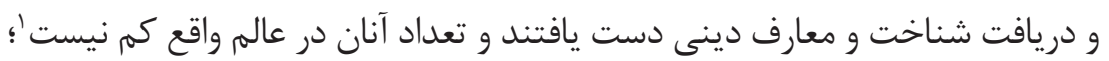

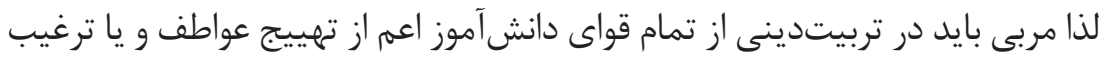

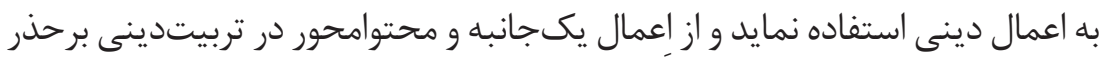

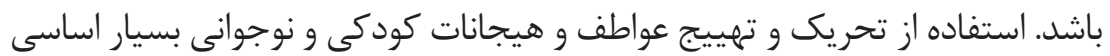

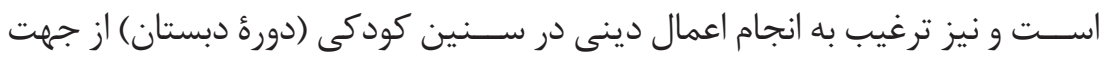

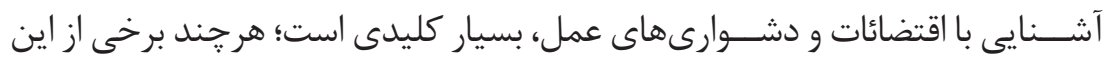

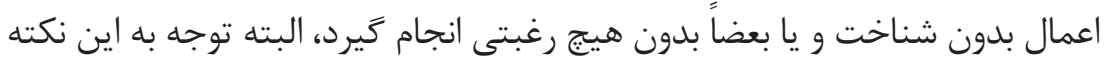

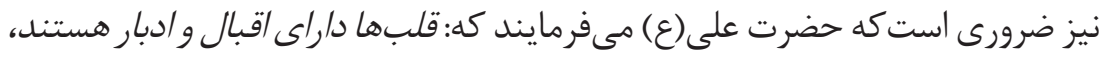

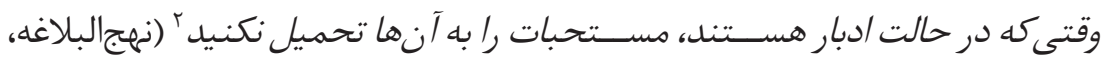

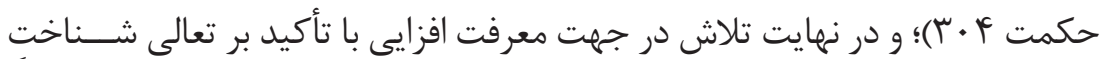

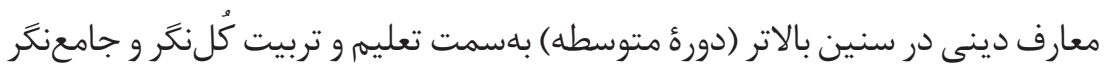

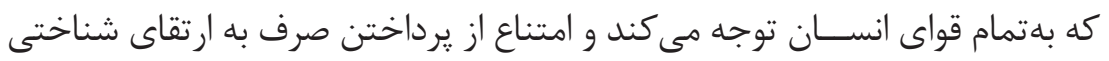

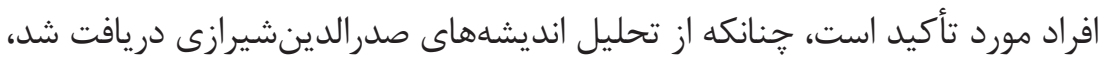

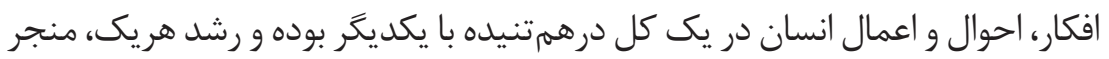

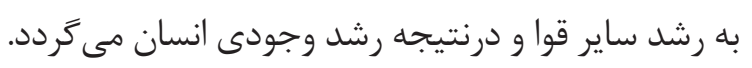

\section{اصل اولويت دادن به تهبييج احوال و انجام اعمال در سنين كودكى(دورهٔ دبسنان):}

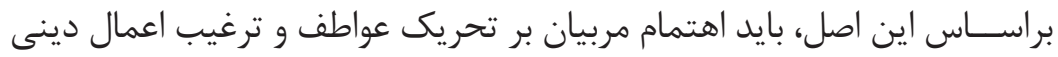

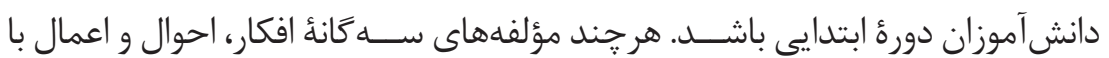




\section{$\Delta \vee-\wedge \wedge$}

يكديخر در تعامل هســتند، اما بايد اولويت در سنين وايينتر بر احساسات و عواطف و اعمال دينى باشــــ. براى نمونه، مى توان استفاده از فعاليتهاى احساسى و هنرى،

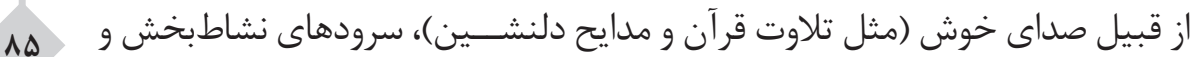
دلنشـــين، نقاشــى و طراحى و كاريكاتور، هنرها و نمايشهاى سنتى و آيينى مهيج، تخــش فيلم، نمايش و ايفاى نقش (محاكات)، داســتان و حكايت و نيز فعاليتهاى عملى، جون دادن مسئوليت در اعمال خيرخواهانهُ دينى گروهى، تمرينهاى معنويت در فعاليتهاى ورزشـى و تحصيلى، زيارت دســتهجمعى، انجام تمرينى مراسمهاى مذهبى مانند نماز جماعت، حضور در هيئات مذهبى، روزه تمرينى ماه مبارك رمضان

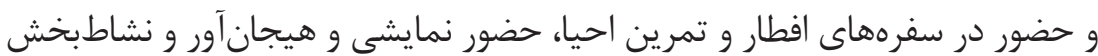
در راهي ريمايیىهاى آئينى، ملاقات با بزرَّان و عالمان دينى و خانواده شهدا و مصاحبت با آنها و نيز ارج نهادن به اين اعمال با اهداى جوايز را، با توجه به ظرفيتهاى روحى و جسمى دانشآموزان و يرهيز از هر گونه افراط مدنظر قرار داد. نكته ظريف در اين نوع فعاليتهاى عملى، وجه تمرينى بودن آنهاست و اگر به اين نكته توجه شود، نسبت به جزئيات، سخت گيرى و وسواس به خرج داده نمىشود.

\section{ه اصل الهميت به شناخت نظرى در سنين بالاتر (دوره متوسطه):}

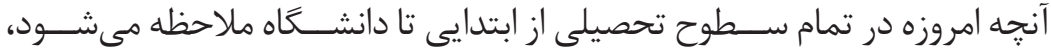

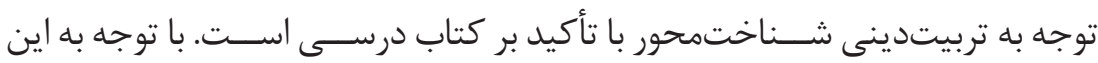
اصل، تربيتدينى محتوامحور در دورهُ متوسطه و بعد از آن كاربردى اساسى داشته و دانشآموزان را كه در دوران دبستان با عواطف و اعمال دينى، خو گرفتهاند به درجات

$$
\text { بالاترى از لحاظ شناخت نيز رهنمون مى }
$$

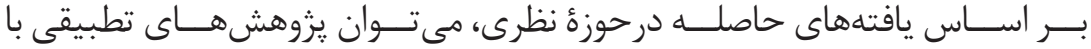
انديشمندان و حكماى عالم غرب را : ييشنهاد داد. همجنين پيشنهاد مى گردد يرسشهاى اين :ثروهش در نظرات ساير فيلســـوفان مسلمان بررسى گردد. به نظر مىرسد با مداقه

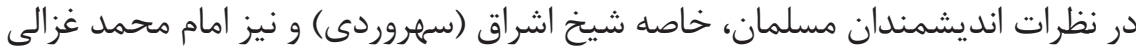
بتوان نتايجى شبيه نتايج اين تحقيق را در خصوص دور هرمنوتيك ميان افكار، احوال و

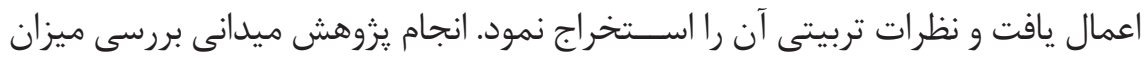


تأثير دور هرمنوتيك ميان افكار، احوال و اعمال و نتايج تربيتدينى آن در اهداف و اصول و اثربخشى آن در تربيتدينى از ديخر ييشنهادهاى يزوهشى اين مطالعه است.

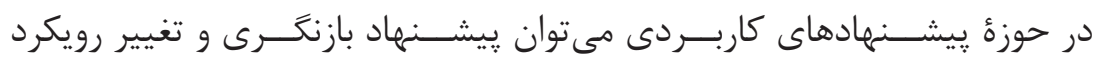
نظامآموزشــى به تربيتدينى را كفت. مســــولان امر تربيت، برنامه نويسان و متوليان

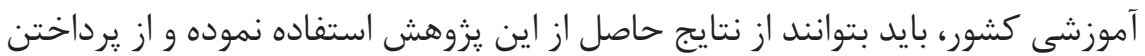
صــرف و تكليفى به مباحث نظرى در تربيتدينى ترهيــز نمايند و به ارائهُ برنامههاى

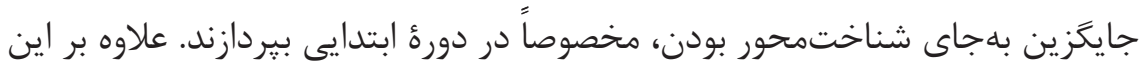

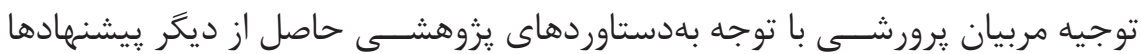

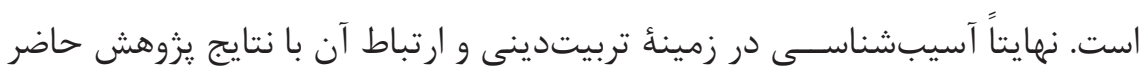
از ديخر ييشـــنهادها است. اهميت اين نوع فعاليتها در دروس :رورشى نهتنها كمتر از دروس نظرى نيست بلكه با توجه به اينكه تربيتدينى جترى بر روى تمامى فعاليتهاى آموزشى در نظر گرفته مىشود بيش از آموزش است. جديد بودن موضوع و عدم وجود ييشـــينهُ قوى، در خصوص دور هرمنوتيك ميان افكار، احوال و اعمال در حكمت متعاليه و عدم ترجمه فارســى بسيارى از منابع دسته اول از اهم محدوديتها و دشوارىهاى اين يزوهش بود.

\section{تشكّر و قدردانى:}

از تمام اساتيد بزر گوار در دانشعاه فردوسى مشهد و تربيت مدرس كه در انجام اين

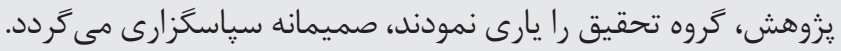




\section{منابع}

نهججالبلاغه (IrVq). ترجمه محمد دشتى. قم: نشر مشهور

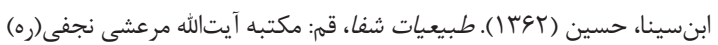

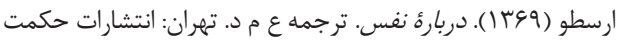

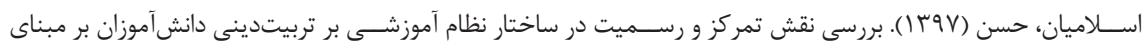

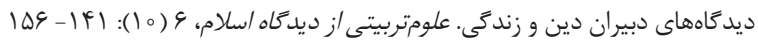

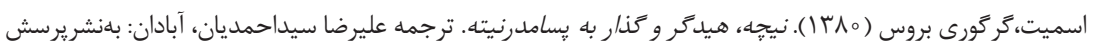

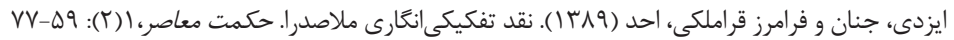

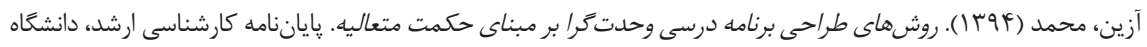

علامه طباطبايى

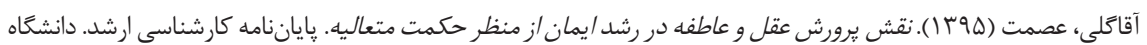

شهيد بهشتى

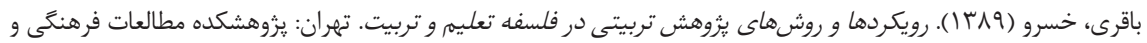

اجتماعى إنى

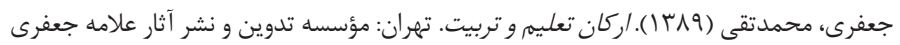

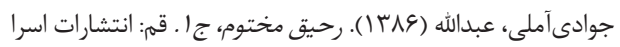

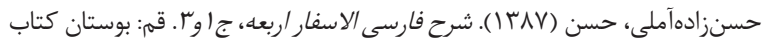

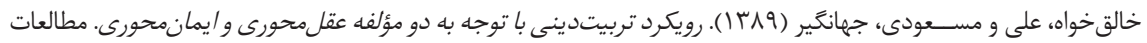

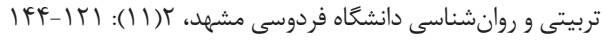

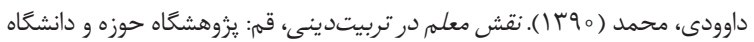

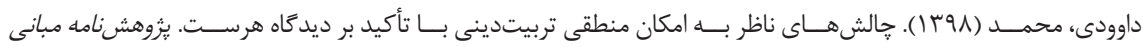

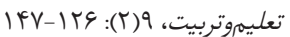

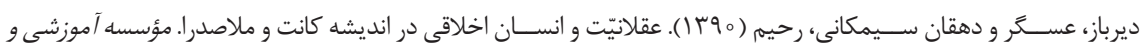

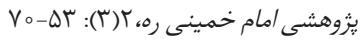

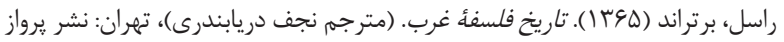

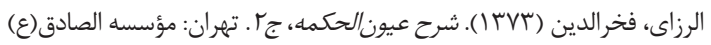

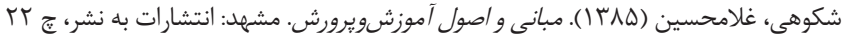

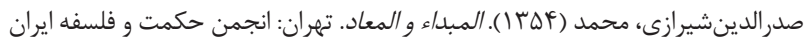

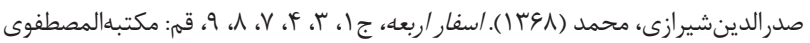

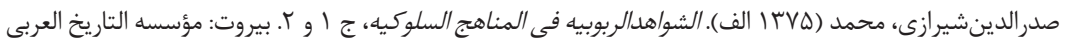

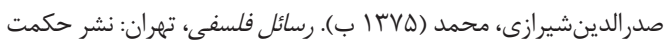

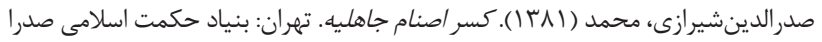

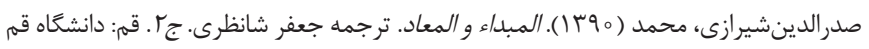

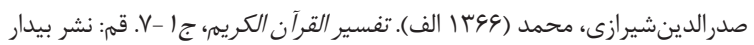

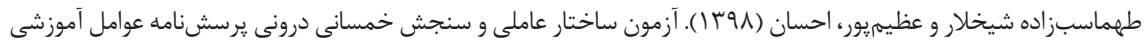

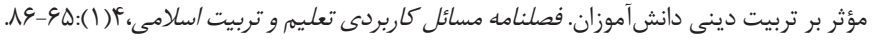

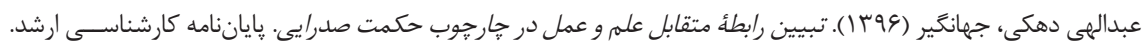

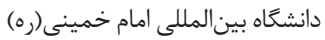

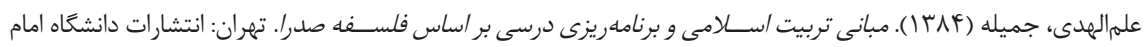
صادق(ع) 


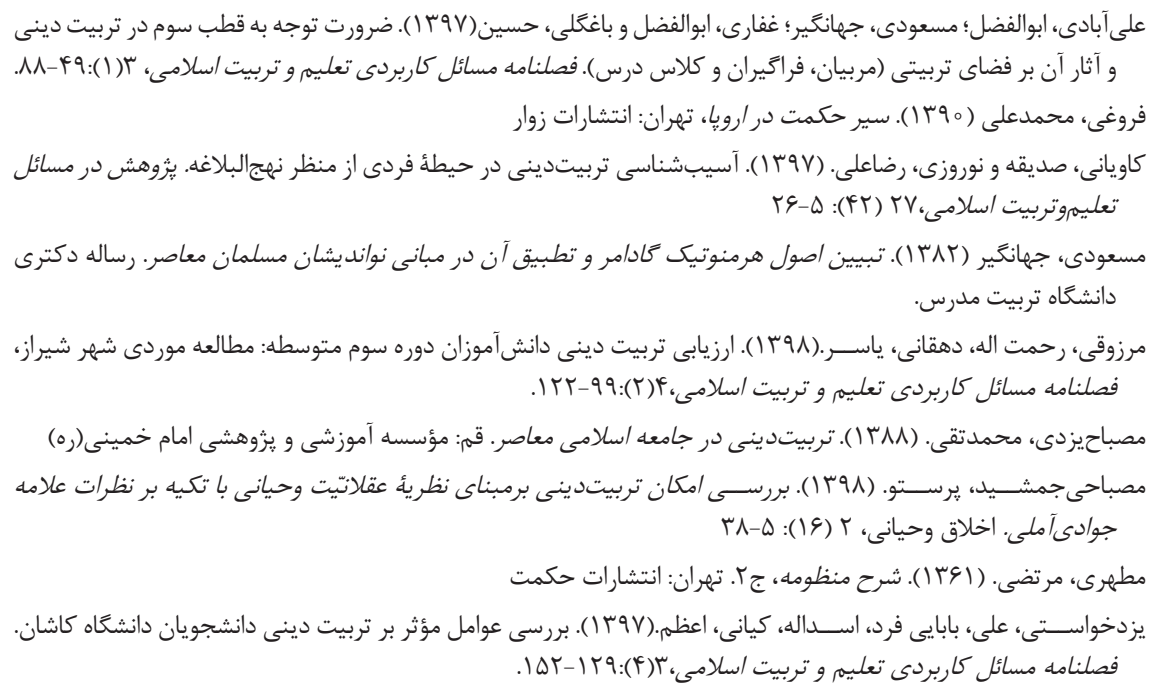

\section{REFERENCES}

Boell, S. K., \& Cecez-Kecmanovic, D. (2010). Literature reviews and the hermeneutic circle. Australian Academic \& Research Libraries, 41(2), 129-144.

Dancy, J., \& Sandis, C. (Eds.). (2015). Philosophy of action: an anthology. John Wiley \& Sons. Edgar, A. (2013). A hermeneutics of sport. Sport, Ethics and Philosophy, 7(1), 140167-

Lawler, J., Trevatt, P., Elliot, C., \& Leary, A. (2019). Does the Diabetes Specialist Nursing workforce impact the experiences and outcomes of people with diabetes? A hermeneutic review of the evidence. Human resources for health, 17(1), 65. 